\title{
Effect of Dry Heat Temperature and Moist Heat Pressure on Canola Meal for Ruminant Utilisation. Part II: Maillard Reaction Product Formation and Structural Characteristics
}

\author{
Rebecca Alice Louise Heim ${ }^{1} \&$ Gaye Louise Krebs ${ }^{2}$ \\ ${ }^{1}$ ARC Industrial Transformation Training Centre for Functional Grains, Graham Centre For Agriculture and \\ Innovation, Charles Sturt University, Wagga Wagga, NSW, Australia \\ ${ }^{2}$ School of Animal and Veterinary Sciences, Charles Sturt University, Wagga Wagga, NSW, Australia \\ Correspondence: Rebecca Alice Louise Heim, ARC Industrial Transformation Training Centre for Functional \\ Grains, Graham Centre For Agriculture and Innovation, Charles Sturt University, Wagga Wagga, NSW, Australia. \\ Tel: 1-614-3046-9171. E-mail: rebarnett@csu.edu.au
}

$\begin{array}{lcc}\text { Received: April 2, 2018 } & \text { Accepted: July 6, 2018 } & \text { Online Published: September 15, } 2018 \\ \text { doi:10.5539/jas.v10n10p10 } & \text { URL: https://doi.org/10.5539/jas.v10n10p10 }\end{array}$

\begin{abstract}
The effects of a range of barrel dry heat temperatures $\left(20\right.$ to $\left.180{ }^{\circ} \mathrm{C}\right)$, and moist heat pressure (MHP) $\left(120^{\circ} \mathrm{C} 15\right.$ min $192 \mathrm{kPa}$ ) on Maillard reaction product (MRP) formation and canola meal structural characteristics were investigated. Increasing dry heat temperature was negatively correlated with meal whiteness $L^{*}$ and yellowness $b^{*}$ (early-MRP) and positively with surface hydrophobicity. Relative to control meal, MHP increased early-MRP, redness, browning index (late-MRP), and acidity; and decreased $L^{*}$, surface hydrophobicity, $b^{*}$, and $\mathrm{Abs}_{294 \mathrm{~nm}}$ (intermediate-MRP). Dry heat-associated changes in surface hydrophobicity suggest protein unfolding and side-chain modifications. Lack of high MW polypeptides at dry heat temperatures of 160 and $180{ }^{\circ} \mathrm{C}$ imply protein denaturation and formation of insoluble polypeptides. Specific dry heat temperatures increased surface lipid and induced the formation of protein matrix and aggregation. Meal surface morphology rounded and flattened at specific dry heat temperatures, and smoothed with MHP. Differences in lipid-related functional groups were evident between dry heat temperatures, and with MHP. Treatment with MHP affected amide I and II, $\alpha$-helix, $\beta$-sheet, their respective ratios and the total protein fingerprint region; fragmented meal into proteolysis-resistant protein aggregates with crevices containing lipid droplets; and, reduced solubility of canola meal polypeptides $>40 \mathrm{kDa}$. The changes observed may have a great effect on ruminal degradation and supply of protein and AA for ruminant utilisation.
\end{abstract}

Keywords: Brassica napus, canola meal, dairy cow, expeller, maillard reaction, microscopy

\section{Introduction}

Canola (rapeseed, Brassica spp. napus, rapa, and juncea) meal is a derivative of seed oil production utilised as a protein supplement in dairy cattle (Sánchez \& Claypool, 1983; Santos, 2011) and feedlot (He et al., 2013; Williams et al., 2008) rations. To extract seed oil and generate meal, solvent-based and mechanical (e.g., cold-press, expeller, and extrusion) processing technologies exist. Expeller extraction utilises dry heat (95 to 135 $\left.{ }^{\circ} \mathrm{C}\right)$ (Newkirk, 2009), and, cold-press extraction mechanically presses seeds by frictional force $\left(\leq 65^{\circ} \mathrm{C}\right)$ (Leming $\&$ Lember, 2005). The formation of heat-damaged protein from the Maillard reaction during processing is of concern for ruminant nutritionists, as it contributes to ruminal insoluble undegraded CP (RUP) levels without providing nutritional benefit (Ross et al., 2013). During the oil extraction process, protein digestibility may be reduced by the formation of compounds that inhibit digestive enzymes and/or the modification of the protein molecule, for example, blocking of active amino acid (AA) side-chains, and/or the formation of crosslinks (Mauron, 1990). Traditionally, acid detergent insoluble nitrogen (ADIN) was utilised to monitor heat-damage protein; however, ADIN does not quantitatively account for all Maillard reaction products (MRP). Therefore, it is of interest to quantify production of MRP during processing of canola meal utilising other established techniques, for instance $\mathrm{pH}, \mathrm{UV} / \mathrm{Vis}$ absorbance at $294 \mathrm{~nm}$ (Ajandouz et al., 2001), colorimetry, and gel electrophoresis (Liu et al., 2014). 
To increase post-ruminally available protein in canola seed and meal, prior studies sought to lower ruminally-degraded protein by chemical (e.g. formaldehyde) and physical treatments (e.g. dry and moist heat pressure (MHP)). To monitor changes in ruminal digestibility, economical, high-throughput and non-invasive substitutes to in vivo, in situ, and in vitro ruminal fluid techniques have been developed. For instance, proteolytic assays, mathematical models (Lopez, 2005), near infrared reflectance spectroscopy (White \& Ashes, 1999), and attenuated total reflectance-Fourier transform infrared (ATR-FTIR) molecular spectroscopy (Peng et al., 2014; Samadi et al., 2013; Theodoridou \& Yu, 2013). Notably, changes in molecular structure resulting from dry and MHP treatments have been investigated in canola seed (Samadi et al., 2013) and tissue (Yu, 2013). In addition, high correlation between changes in the molecular protein structure of canola meal and ruminal protein degradability in dairy cattle was observed (Peng et al., 2014; Theodoridou \& Yu, 2013).

The resistance of protein structure to enzymatic degradation has been qualified by confocal laser scanning microscopy (CLSM) (Jha et al., 2015) and scanning electron microscopy (Jha et al., 2015; Zhang et al., 2009). Although the effects of solvent-extraction processing on the microscopic structure of rapeseed meal were reported (Yiu et al., 1983), little is known of the microscopic structure of canola meal resulting from other processing techniques and heat treatments, and the characteristics which favour resistance to enzymatic degradation.

The hypothesis tested in the current study was that the level of MRP formation and structural characteristics in expeller-extracted canola meal would differ depending on the processing and treatment conditions. The objectives of this study were to investigate the effect of barrel dry heat temperature range and MHP treatment on MRP formation and structural characteristics of canola meal.

\section{Method}

\subsection{Canola Meal and Suspension Preparation}

\subsubsection{Canola}

The canola used is as described in the accompanying paper (Heim \& Krebs, 2018).

\subsubsection{Barrel Dry Heat and Moist Heat Pressure of Canola}

The design for this study was described in the accompanying paper (Heim \& Krebs, 2018).

\subsubsection{Preparation of Canola Meal Pellets and Suspensions}

To prepare circular pellets, canola meal $(\sim 0.2 \mathrm{mg})$ was pressed at 100 bar utilising an Enerpac Hydraulic Press. The canola meal suspensions were generated as described in the accompanying paper (Heim \& Krebs, 2018).

\subsection{Characterisation of the Maillard Reaction}

\subsubsection{Measurement of Colour}

To quantify colour, the meals were placed in a lidded cuvette then colour was measured with a Chroma Meter CR-300 colorimeter (Minolta CO., Osaka, Japan), using the CIE-Lab tristimulus system, calibrated with a white tile and a D-65 illuminant source. The $a^{*}$ (red to green), $b^{*}$ (yellow to blue), $L^{*}$ (white to black), degree of colour change $(\Delta E)$ and browning index $(\mathrm{BI})$ were calculated as previously described (Bal et al., 2011).

\section{$2.2 .2 \mathrm{pH}$}

The meal suspensions were examined for $\mathrm{pH}$ by magnetic stirring using a PHM 93 Reference meter (Radiometer, Copenhagen) calibrated with buffer solutions at $\mathrm{pH} 4$ and 7.

\subsubsection{Determination of UV/Vis Absorbance at $294 \mathrm{~nm}$}

The meal suspensions were analysed for UV Vis absorbance utilising an adaption of the Ajandouz et al. (2001) procedure. The meal suspension $(20 \mu \mathrm{L})$ was added to deionised $\mathrm{H}_{2} \mathrm{O}(80 \mu \mathrm{L})$ in a clear flat bottom non-absorbent 96 F $400 \mu \mathrm{L}$ Microwell microplate (Nunc, \#269620), and UV/Vis Abs $294 \mathrm{~nm}$ was measured utilising a CLARIOstar 5.20 R5 microplate reader (BMG Labtech, Offenburg, Germany).

\subsection{Surface Hydrophobicity Measurement}

The meal suspensions were analysed in duplicate for surface hydrophobicity $(\mathrm{So})$ with fluorescence probes (Nakai, 2001). Under darkened conditions, an aliquot of suspension was made up to a final volume of $300 \mu \mathrm{L}$ using $0.01 \mathrm{M}$ sodium tetraborate solution $\mathrm{pH} 6$ in a $400 \mu \mathrm{L}$ 96-well microplate (Nunc ${ }^{\mathrm{TM}}$ F96 MicroWell ${ }^{\mathrm{TM}}$ Black Polystyrene 237105). To each well, $1 \mu \mathrm{L}$ of 1-anilino-8-naphthalene sulfonate (ANS, Fluka 10419) reagent was added. The plate was incubated at $25^{\circ} \mathrm{C}$ for $2 \mathrm{~min}$, and then shaken at $500 \mathrm{rpm}$ for $10 \mathrm{sec}$ in a CLARIOstar 5.20 R5 microplate reader. Fluorescence intensity was measured at an excitation maximum of 390 to $405 \mathrm{~nm}$ and an 
emission maximum of 470 to $500 \mathrm{~nm}$. Values were corrected by deducting an average of blank measurements. A 0 to $200 \mu \mathrm{g} / \mu \mathrm{L}$ standard curve was established using a $1 \mathrm{M}$ stock solution of bovine serum albumin (Sigma) prepared in $0.01 \mathrm{M}$ sodium tetraborate solution and stored in the dark at $4{ }^{\circ} \mathrm{C}$.

\subsection{ATR-FTIR Sample Preparation, Data Collection and Analysis}

The molecular spectral data of canola meal pellets were generated by ATR-FTIR 8400S (Shimadzu Corp., Kyoto, Japan) with a single reflection plate, flat tip, constant pressure (530 psi), in absorbance mode (40 scan runs, 4 $\mathrm{cm}^{-1}$, Happ-Genzel apodisation, mid-IR, ca. 4000 to $\left.600 \mathrm{~cm}^{-1}\right)$. The data was collected utilising IR Solution software, baseline corrected as described by Zhang et al. (2009), and total peak normalised. The lipid and protein functional groups were identified as described (Samadi et al., 2013; Samadi \& Yu, 2012). The IR total protein fingerprint region (TPFR) ca. 1714 to $1480 \mathrm{~cm}^{-1}$ included amide I (area ca. 1714 to $1571 \mathrm{~cm}^{-1}$ ), amide II (area ca. 1572 to $1480 \mathrm{~cm}^{-1}$ ), $\alpha$-helix (peak centre height at ca. $1652 \mathrm{~cm}^{-1}$ with the baseline of ca. 1714 to $1480 \mathrm{~cm}^{-1}$ ) and $\beta$-sheet (peak centre height at ca. $1630 \mathrm{~cm}^{-1}$ with the baseline of ca. 1714 to $1480 \mathrm{~cm}^{-1}$ ). Lipid regions included the lipid unsaturated band $\mathrm{C}=\mathrm{C}\left(\mathrm{ULB}\right.$, peak height centre at ca. $\left.3007 \mathrm{~cm}^{-1}\right)$, carbonyl $\mathrm{C}=\mathrm{O}$ ester stretching band (LCCE, baseline ca. 1789 to $1701 \mathrm{~cm}^{-1}$ with peak height ca. $\left.1744 \mathrm{~cm}^{-1}\right), \mathrm{CH}_{3}$ asymmetric $\left(\mathrm{CH}_{3 \mathrm{~A}}\right.$ ca. 2988 to 2951 $\mathrm{cm}^{-1}$ with peak centre height at ca. $\left.2955 \mathrm{~cm}^{-1}\right), \mathrm{CH}_{2}$ asymmetric $\left(\mathrm{CH}_{2 \mathrm{~A}}\right.$ ca. 2951 to $2882 \mathrm{~cm}^{-1}$ with peak centre height at ca. $\left.2922 \mathrm{~cm}^{-1}\right), \mathrm{CH}_{3}$ symmetric $\left(\mathrm{CH}_{3 \mathrm{~S}}\right.$ ca. 2882 to $2868 \mathrm{~cm}^{-1}$ with peak centre height at ca. $\left.2872 \mathrm{~cm}^{-1}\right)$ and $\mathrm{CH}_{2}$ symmetric $\left(\mathrm{CH}_{2 \mathrm{~S}}\right.$ ca. 2868 to $2790 \mathrm{~cm}^{-1}$ with peak centre height at ca. $\left.2852 \mathrm{~cm}^{-1}\right)$.

\subsection{Gel Electrophoresis of Meal Protein Profiles and Extent of Maillard Reaction}

\subsubsection{SDS-Polyacrylamide Gel Electrophoresis (PAGE)}

The polypeptide banding profile of the meals was visualised utilising SDS-PAGE. The sample $(\sim 10 \mathrm{mg}$ CP $)$ was dissolved in sample buffer ( $1 \mathrm{~mL}: 11.25 \mathrm{mM}$ tris- $\mathrm{HCl}, \mathrm{pH} 8.5,3.6 \% \mathrm{SDS}, 18 \%$ glycerol, $0.0025 \%$ bromophenol blue), and heated at $85{ }^{\circ} \mathrm{C}$ for $10 \mathrm{~min}$. For reducing conditions, $50 \mathrm{mM}$ DTT was added to the sample buffer. The protein sample $(30 \mu \mathrm{g}$ of $\mathrm{CP}$ per well) and standard marker $(5 \mu \mathrm{L}$, Novex Mark 12, Invitrogen, Victoria, Australia) were loaded onto a NuPAGE gradient precast gel (4 to $12 \%$ gradient) BisTris $\left(10 \times 10 \mathrm{~cm}^{2}\right)$ in a Novex Xcell Mini cell system (Invitrogen, Victoria, Australia). Electrophoresis was performed at $80 \mathrm{~V}$ for 75 min, followed by $90 \mathrm{~V}$ for $75 \mathrm{~min}$ in running buffer $(50 \mathrm{mM}$ MES, $50 \mathrm{mM}$ tris base, $0.1 \%$ SDS, $1 \mathrm{mM}$ EDTA, $\mathrm{pH}$ 7.3). The polypeptide bands were visualised by incubating the gel in coomassie brilliant blue R-250 solution $\left(0.1 \%\right.$ in $\left.40 \% \mathrm{CH}_{3} \mathrm{OH}, 10 \% \mathrm{CH}_{3} \mathrm{CO}_{2} \mathrm{H}\right)$ for $25 \mathrm{~min}$, and de-stain $\left(10 \% \mathrm{CH}_{3} \mathrm{CH}_{2} \mathrm{OH}, 7.5 \% \mathrm{CH}_{3} \mathrm{CO}_{2} \mathrm{H}\right)$ on an orbital shaker at room temperature $\left(\mathrm{RT}, \sim 21^{\circ} \mathrm{C}\right)$ overnight.

\subsubsection{Native Gel Electrophoresis}

Native gel-electrophoresis was used to establish the protein profiles of the meals. This was performed using a NativePage 4 to $16 \%$ gradient precast BisTris $\left(10 \times 10 \mathrm{~cm}^{2}\right)$ gel in a Novex Xcell Mini cell (Invitrogen, Victoria, Australia). The electrophoresis running buffer contained $50 \mathrm{mM}$ BisTris, $50 \mathrm{mM}$ tricine, $\mathrm{pH} 6.8$, and sample buffer contained $50 \mathrm{mM}$ BisTris, $6 \mathrm{~N} \mathrm{HCl}, 50 \mathrm{mM} \mathrm{NaCl}, 10 \% \mathrm{w} / \mathrm{v}$ glycerol, $0.001 \%$ Ponceau S, pH 7.2. Protein samples were re-suspended in borate-phosphate (BP) buffer $(\mathrm{pH} 6.7)$ to achieve $(10 \mu \mathrm{g} / \mu \mathrm{L})$, then $3 \mu \mathrm{L}$ was dissolved in $2.5 \mu \mathrm{L}$ NativePage sample buffer (4X), $1 \mu \mathrm{L}$ NativePage 5\% G-250 sample additive, and made to 10 $\mu \mathrm{L}$ with deionised $\mathrm{H}_{2} \mathrm{O}$. The protein samples $(30 \mu \mathrm{g}$ of protein per well) and $5 \mu \mathrm{L}$ of NativeMark unstained protein standard (LC0725, Invitrogen, Victoria, Australia) were loaded onto the gel. The upper (inner) buffer chamber was filled with $200 \mathrm{~mL}$ cathode buffer $(10 \mathrm{~mL}$ NativePage running buffer $20 \mathrm{X}, 10 \mathrm{~mL}$ NativePage cathode additive 20X), and the lower (outer) buffer chamber was filled with $600 \mathrm{~mL}$ of the anode buffer (50 mL NativePage running buffer (20X), $950 \mathrm{~mL}$ deionised $\mathrm{H}_{2} \mathrm{O}$ ). Electrophoresis was performed at $150 \mathrm{~V}$ for $110 \mathrm{~min}$. Gels were fixed in $40 \% \mathrm{CH}_{3} \mathrm{OH}$ and $10 \% \mathrm{CH}_{3} \mathrm{CO}_{2} \mathrm{H}$ for $25 \mathrm{~min}$. Proteins were visualised by staining the gel with coomassie brilliant blue R-250 fixing solution $\left(0.02 \%\right.$ in $\left.30 \% \mathrm{CH}_{3} \mathrm{OH}, 10 \% \mathrm{CH}_{3} \mathrm{CO}_{2} \mathrm{H}\right)$ for $25 \mathrm{~min}$, then de-staining in $8 \% \mathrm{CH}_{3} \mathrm{CO}_{2} \mathrm{H}$ by shaking on an orbital shaker at RT overnight.

\subsection{Confocal Laser Scanning Microscopy}

The microscopic structure of the meals and in vitro proteolytic digested RUP residues were determined utilising a TCS SP5 confocal laser-scanning microscope (CLSM, Leica Microsystems, Wetzlar, Germany) fitted with a 20x oil immersion objective. The meal $(100 \mathrm{mg})$ was fluorescently labelled in FCF Fast Green (1 drop, $0.4 \%$ in $\mathrm{H}_{2} \mathrm{O}$ ) and Nile Blue (1 drop, $0.5 \%$ in $\mathrm{H}_{2} \mathrm{O}$ ) dye, to stain for protein and lipid, then excited at 633 and $488 \mathrm{~nm}$, and reflected emitted light was collected at 662 to 744, and 520 to $626 \mathrm{~nm}$, with HeNe and Ar lasers, respectively. 


\subsection{Scanning Electron Microscopy}

The meals and in vitro proteolytic digested RUP residues were adhered to aluminium sample holders using double-sided carbon tabs (Smoothest Carbon Tabs, ProSciTech). The samples were imaged in a Hitachi S4300 $\mathrm{SE} / \mathrm{N}$ variable pressure SEM. The environmental secondary electron detector was used with a pressure of $50 \mathrm{~Pa}$, accelerating voltage of $20 \mathrm{kV}$, RT and a working distance of $15 \mathrm{~mm}$.

\subsection{Mass Spectrometry Analysis}

For NanoLC-ESI-MS/MS peptide identification (undertaken at the Monash Biomedical Proteomics Facility), NativePage pieces underwent preparation by rehydration with $2.5 \mathrm{mM}$ DTT for $30 \mathrm{~min}$, then alkylation with 10 $\mathrm{mM}$ iodoacetamide for $30 \mathrm{~min}$ at RT in the dark. The gel slices were incubated with $1 \mu \mathrm{g}$ trypsin (Promega corp. Madison, WI, USA) in $20 \mathrm{mM} \mathrm{NH} \mathrm{NHCO}_{3}$ at $37{ }^{\circ} \mathrm{C}$ overnight. Tryptic digests were analysed by NanoLC-ESI-MS/MS using a QExactive mass spectrometer (Thermo Scientific, Bremen, Germany) coupled online with a RSLC nano HPLC (Ultimate 3000, Thermo Scientific, Bremen, Germany). Extracted peptide samples were concentrated with $0.01 \% \mathrm{HCO}_{2} \mathrm{H}$ (in $\mathrm{H}_{2} \mathrm{O}$ to $95 \%$ ) on a PepMap $\mathrm{C} 18$ trap column-nano Viper (5 $\mu \mathrm{m}, 100 \mu \mathrm{m} \times 2 \mathrm{~cm}, 100 \AA$, Thermo Dionex) at $15 \mu \mathrm{L} / \mathrm{min}$ flow rate. Eluted peptides were separated on an Acclaim PepMap C18 RSLC $(2 \mu \mathrm{m}, 75 \mu \mathrm{m} \times 50 \mathrm{~cm}, 100 \AA$, Thermo Scientific $)$ with a $300 \mathrm{~nL} / \mathrm{min}$ flow rate and gradient of: $0.09 \% \mathrm{HCO}_{2} \mathrm{H}, 30$ min; $24 \% \mathrm{CH}_{3} \mathrm{CN}, 0.03 \% \mathrm{HCO}_{2} \mathrm{H}, 25 \mathrm{~min} ; 32 \% \mathrm{CH}_{3} \mathrm{CN}, 0.04 \% \mathrm{HCO}_{2} \mathrm{H}$. The eluent was nebulised and ionised using a Thermo nano electrospray source with a distal coated fused silica emitter (New Objective, Woburn, MA, USA) set at $1.9 \mathrm{kV}$. Peptides were selected for MS/MS in full MS/dd-MS 2 in TopN setting mode: TopN 10, 17,500 resolution, MS/MS AGC target 1e5, 6-ms Max IT, NCE 27, a $3 \mathrm{~m} / \mathrm{z}$ isolation window, $10 \%$ underfill ratio, and $15 \mathrm{~s}$ dynamic exclusion. All LC MS/MS data were exported to Mascot (*mgf), using proteowizard 3.0.3631 software and searched against Swiss-Prot databases using the MASCOT search engine v2.4, Matrix Science Inc. London, UK) with settings: all species, 20 ppm peptide tolerance, $20 \mathrm{mmu}$ MS/MS fragment tolerance, fixed modification: carbamindomethylation, variable modification: oxidation.

\subsection{Statistical Analysis}

All statistical analyses of data were performed as described in the accompanying paper (Heim \& Krebs, 2018).

\section{Results}

The effects of dry heat $\left(20\right.$ to $\left.180^{\circ} \mathrm{C}\right)$ with MHP on MRP formation and structural characteristics of canola meal are presented in Table 1 (and Table A1). As dry heat temperature increased the yellowness of meal decreased ( $b^{*}$, $\left.\mathrm{r}_{s}=-0.65, P<0.05\right)$, whiteness decreased $\left(L^{*}, \mathrm{r}_{s}=-0.77, P<0.05\right)$, and redness remained similar $\left(a^{*}, \mathrm{r}_{s}=0.56\right)$. Increased dry heat temperature with MHP decreased meal yellowness $\left(\mathrm{r}_{s}=-0.70, P<0.05\right)$, and whiteness $\left(\mathrm{r}_{s}=\right.$ $-0.78, P<0.05)$, whereas redness was unchanged $\left(\mathrm{r}_{s}=0.13\right)$. Compared to the control, MHP meal was bluer (6.24 vs. 13.6, $P<0.01)$, and blacker (49.8vs. 58.7, $P<0.05)$, and redder $(6.01 v s .2 .01, P<0.01)$. Yellowness was greatest between dry heat temperatures of 20 to $120^{\circ} \mathrm{C}$ in the control $(P<0.05)$, and among 20 to $140{ }^{\circ} \mathrm{C}$ in MHP meals $(P<0.01)$. Whiteness was greatest $(P<0.01)$ from 20 to $100{ }^{\circ} \mathrm{C}$ in the control, and 20 to $140{ }^{\circ} \mathrm{C}$ in MHP meals. No difference in redness between dry heat temperatures was apparent in the control and MHP meals. The degree of colour change from MHP was similar between dry heat temperatures. Levels of BI were less $(P<$ $0.01)$ in control (73.5\%) compared to the MHP (142\%) meals.

For both the control and MHP meals $\mathrm{pH}$ did not vary among dry heat temperatures $(P>0.05$, Table 1$)$. Acidity was less $(P<0.01)$ in the control $(6.65)$ compared to the MHP $(6.55)$ meal suspensions. Intermediate-MRP formation was similar $(P>0.05)$ at all dry heat temperatures in the control and MHP meal suspensions (Table 1). Intermediate-MRP formation was higher $(P<0.01)$ in the control $(2.00)$ than in MHP meals $(0.97)$. No associations $(P>0.05)$ were observed between dry heat temperatures and intermediate-MRP formation in control $\left(\mathrm{r}_{s}=-0.35\right)$ and MHP $\left(\mathrm{r}_{s}=-0.05\right)$ meals. For both the control and MHP meal suspensions $S o$ varied $(P<$ 0.05 ) between dry heat temperatures (Table 1). A positive correlation was observed between $S o$ and dry heat temperature in control $\left(\mathrm{r}_{s}=0.64, P<0.05\right)$ and MHP meal suspensions $\left(R^{2}=0.87\right)$. Average $S o$ was greater $(P<$ $0.05)$ in the control (5.65) than in MHP meal suspensions (4.32).

Infrared molecular spectroscopic characteristics of protein structure (absorbed area intensity of the TPFR, and height intensities of $\alpha$-helix, $\beta$-sheet, amide I and II, and their respective ratios) of canola meal processed with increasing dry heat $\left(20\right.$ to $180{ }^{\circ} \mathrm{C}$ ) with MHP are presented in Table 2 (and Figure A1). In control meals, these functional groups were unaffected by dry heat. Compared to the control, MHP decreased amide I $(P<0.05)$, amide II, $\alpha$-helix, $\beta$-sheet and TPFR $(P<0.01)$, and increased $(P<0.05)$ the ratio of $\alpha$-helix to $\beta$-sheet, and amide I to II. Infrared molecular spectroscopic characteristics of lipid structure (absorbed height intensities of 
$\mathrm{CH}$ functional groups, unsaturated and carbonyl ester $\mathrm{C}=\mathrm{O}$ stretching bands) of canola meal processed with increasing dry heat temperature $\left(20\right.$ to $\left.180{ }^{\circ} \mathrm{C}\right)$ with MHP are shown in Table 3 (and Figure A1). Although dry heat induced changes $(P<0.01)$ in all lipid functional groups studied, the ratios of $\mathrm{CH}_{3}: \mathrm{CH}_{2 \mathrm{AS}}$ and $\mathrm{CH}_{3}: \mathrm{CH}_{2} \mathrm{~S}$ were similar. Treatment with MHP did not affect lipid functional groups, other than by reducing $(P<0.01)$ the ratio of $\mathrm{CH}_{3}: \mathrm{CH}_{2} \mathrm{~s}$.

The gel electrophoresis analysis of water soluble, buffer soluble and native protein subunits of control and MHP meals are shown in Figure 1 (and Figures A2 to A4). In non-reduced conditions, polypeptide bandings included: $\sim 177, \sim 118,76.8,73.5,41$ to $55,37.1,28.5,27.5,26.7,22.9,21.1,18.3$, and $14 \mathrm{kDa}$. Under reducing conditions polypeptide bands of 41 to 55 , and $14 \mathrm{kDa}$ disappeared; and, 9.6 to 32.0, 9 and $4 \mathrm{kDa}$ appeared. Polypeptide bands present under control and reducing conditions were 18 to $25,27,39$ and $41 \mathrm{kDa}$. In control meals, dry heat of 160 and $180{ }^{\circ} \mathrm{C}$ reduced the solubility of polypeptides greater than $\sim 55 \mathrm{kDa}$. At 20 to $180{ }^{\circ} \mathrm{C}$, MHP hindered soluble protein extraction and reduced solubility of polypeptides greater than $\sim 40 \mathrm{kDa}$. Native conformation of water soluble canola meal proteins consisted of a 300 to $400 \mathrm{kDa}$ protein band and protein smearing from 50 to $200 \mathrm{kDa}$. With MHP the 300 to $400 \mathrm{kDa}$ protein band was no longer visible. In BP-buffer, the 300 to $400 \mathrm{kDa}$ protein band was reduced in intensity, and similarly absent after MHP, unlike the protein smearing from 50 to $200 \mathrm{kDa}$. The 300 to $400 \mathrm{kDa}$ protein band most closely matched with peptide sequences corresponding to $B$. napus cruciferin CRU1 (score 13,965, matches 302(180)), cruciferin CRU4 (score 8191, matches 478(149)), cruciferin $\mathrm{BnC} 1 \alpha$ and $\beta$ subunit precursor (score 6590, matches 384(112)), cruciferin $\mathrm{BnC} 2 \alpha$ and $\beta$ subunit precursor (score 4764, matches 251(79)), and napin (score 1,159, matches 48(26)).

Table 1. Monitoring of Maillard reaction product formation and surface hydrophobicity of canola meals produced at increasing barrel dry heat $\left(20\right.$ to $\left.180^{\circ} \mathrm{C}\right)$ with moist heat pressure (MHP)

\begin{tabular}{|c|c|c|c|c|c|c|c|c|c|c|c|c|c|c|}
\hline & \multirow{2}{*}{ MHP } & \multicolumn{8}{|c|}{ Barrel Dry Heat $\left({ }^{\circ} \mathrm{C}\right)$} & \multirow{2}{*}{ - SEM } & \multirow{2}{*}{$P_{B T}$} & \multirow{2}{*}{$P_{M H P}$} & \multirow{2}{*}{$\mathrm{r}_{\mathrm{s}}$} & \multirow{2}{*}{$R^{2}$} \\
\hline & & 20 & 60 & 80 & 100 & 120 & 140 & 160 & 180 & & & & & \\
\hline \multirow[t]{2}{*}{$b^{*}$} & - & $14.8^{\mathrm{abcd}}$ & $13.8^{\mathrm{a}}$ & $14.9^{\mathrm{ac}}$ & $14.4^{\mathrm{abcd}}$ & $14.0^{\mathrm{abcd}}$ & $13.6^{\text {bcd }}$ & $12.2^{\mathrm{cd}}$ & $11.6^{\mathrm{d}}$ & 0.425 & $*$ & \multirow{2}{*}{$* *$} & $-0.65^{*}$ & 0.12 \\
\hline & + & $6.53^{\mathrm{a}}$ & $7.50^{\mathrm{ab}}$ & $7.18^{\mathrm{a}}$ & $6.25^{\mathrm{a}}$ & $6.22^{\mathrm{ab}}$ & $5.58^{\mathrm{abc}}$ & $5.66^{\mathrm{bc}}$ & $5.00^{\mathrm{c}}$ & 0.488 & $* *$ & & $-0.70 *$ & 0.05 \\
\hline \multirow[t]{2}{*}{$a^{*}$} & - & 1.62 & 2.03 & 1.93 & 1.79 & 2.03 & 2.07 & 2.29 & 2.28 & 0.333 & NS & \multirow{2}{*}{$* *$} & 0.56 & 0.08 \\
\hline & + & 5.83 & 6.09 & 6.15 & 5.87 & 5.96 & 6.01 & 6.12 & 6.00 & 0.186 & NS & & 0.13 & 0.12 \\
\hline \multirow[t]{2}{*}{$L^{*}$} & - & $60.4^{\mathrm{abc}}$ & $59.8^{\mathrm{a}}$ & $60.9^{\mathrm{ab}}$ & $60.3^{\mathrm{abc}}$ & $58.9^{\mathrm{bc}}$ & $58.1^{\mathrm{cd}}$ & $56.1^{\text {cd }}$ & $55.4^{\mathrm{d}}$ & 0.422 & $* *$ & \multirow[t]{2}{*}{$*$} & $-0.77^{*}$ & 0.73 \\
\hline & + & $50.2^{\mathrm{a}}$ & $50.9^{\mathrm{a}}$ & $50.6^{\mathrm{a}}$ & $50.0^{\mathrm{a}}$ & $49.8^{\mathrm{ab}}$ & $49.1^{\mathrm{abc}}$ & $49.2^{\mathrm{bc}}$ & $48.3^{\mathrm{c}}$ & 0.447 & $* *$ & & $-0.78^{*}$ & 0.73 \\
\hline$\Delta E_{M H P}$ & + & 13.9 & 11.6 & 13.5 & 13.7 & 12.6 & 12.6 & 10.2 & 10.4 & 0.409 & NS & $* *$ & -0.57 & 0.30 \\
\hline \multirow[t]{2}{*}{$\mathrm{BI}$} & - & 66.4 & 74.0 & 72.6 & 69.6 & 74.4 & 75.0 & 78.4 & 78.0 & 1.276 & NS & \multirow{2}{*}{$* *$} & $0.53 *$ & 0.28 \\
\hline & + & 139 & 145 & 146 & 139 & 141 & 141 & 143 & 140 & 0.780 & NS & & 0.08 & 0.07 \\
\hline \multirow[t]{2}{*}{$\mathrm{pH}$} & - & 6.64 & 6.71 & 6.65 & 6.76 & 6.64 & 6.65 & 6.60 & 6.71 & 0.016 & $\mathrm{NS}$ & \multirow{2}{*}{$* *$} & -0.02 & 0.32 \\
\hline & + & 6.60 & 6.54 & 6.57 & 6.59 & 6.54 & 6.75 & 6.50 & 6.52 & 0.014 & NS & & -0.16 & 0.65 \\
\hline \multirow[t]{2}{*}{ Intermediate MRP $\left(\mathrm{Abs}_{294 \mathrm{~nm}}\right)$} & - & 2.05 & 2.17 & 2.11 & 2.03 & 2.09 & 1.88 & 1.87 & 1.84 & 0.058 & NS & \multirow{2}{*}{$* *$} & -0.35 & 0.18 \\
\hline & + & 0.99 & 0.92 & 1.13 & 0.91 & 0.95 & 0.93 & 0.99 & 0.93 & 0.084 & NS & & -0.05 & 0.01 \\
\hline \multirow[t]{2}{*}{ So $(\%$ of soluble CP) } & - & $4.21^{\mathrm{bc}}$ & $3.98^{\mathrm{c}}$ & $4.42^{\mathrm{bc}}$ & $4.90^{\mathrm{abc}}$ & $4.37^{\mathrm{bc}}$ & $4.18^{\mathrm{c}}$ & $5.58^{\mathrm{ab}}$ & $5.13^{\mathrm{a}}$ & 0.158 & $*$ & \multirow[t]{2}{*}{$*$} & $0.64 *$ & 0.39 \\
\hline & + & $2.59^{\mathrm{c}}$ & $3.46^{\mathrm{c}}$ & $3.39^{\mathrm{c}}$ & $3.14^{\mathrm{c}}$ & $3.39^{\mathrm{c}}$ & $5.44^{\mathrm{b}}$ & $5.99^{\mathrm{ab}}$ & $7.17^{\mathrm{a}}$ & 0.409 & $* *$ & & $0.83^{*}$ & 0.87 \\
\hline
\end{tabular}

Note. MHP $=$ moist heat pressure $\left(120^{\circ} \mathrm{C} 15 \mathrm{~min} 192 \mathrm{kPa}\right)$. The CIE-Lab tristimulus system $a^{*}$ (redness to greeness), $b^{*}$ (yellowness to blueness) and $L^{*}$ (whiteness to blackness), total colour change after MHP treatment $\left(\triangle E_{M H P}\right)$ and browning index $(\mathrm{BI})$ were calculated as described by Bal et al. (2011). MRP $=$ Maillard reaction product; $S o=$ surface hydrophobicity. Means in rows with unlike superscripts differ $(P<0.05)$. SEM $=$ standard error of mean; $\mathrm{r}_{\mathrm{s}}=$ pair-wise Spearman correlation coefficient; $R^{2}=$ coefficient of determination; $P_{B T}=$ difference between barrel temperatures; ${ }^{*} P<0.01 ; * P<0.05 ; \mathrm{NS}=$ not significant.

The effects of increasing dry heat and application of MHP on meal structural organisation, notably protein and lipid, utilising CLSM are presented in Figure 2 (and Figures A5 and A6). At a dry heat temperature of $20{ }^{\circ} \mathrm{C}$ (cold-press) meal exhibited intact cotyledon structure, with little disruption to protein and lipid bodies within cells. At $60^{\circ} \mathrm{C}$, fractured cell walls surrounding the outer edges of meal flakes, in which lipid body coalescence (droplets of $<\sim 2.5 \mu \mathrm{m}$ ) became more pronounced. At $80{ }^{\circ} \mathrm{C}$, protein aggregated within and between cellular walls, to produce heterogeneous matrix. Fusion of individual protein bodies left behind vacuoles or a space within the cell. A noticeable decrease in the number of lipid droplets was observed. Residual lipid was seen trapped between the cells, or in trace amounts of cotyledon embedded within the matrix. At $100{ }^{\circ} \mathrm{C}$, protein 
fusion intensified, small fragments $\sim 10 \mu \mathrm{m}$ of detached protein matrix formed, and trapped residual lipid coalesced into $\sim 2.5 \mu \mathrm{m}$ bodies within the protein matrix. At $120{ }^{\circ} \mathrm{C}$, wider crevices formed in areas where cell walls once existed and many smaller $<2 \mu \mathrm{m}$ lipid droplets were released onto the surrounding outer surface of meal fragments. From 140 to $180{ }^{\circ} \mathrm{C}$, large dense mats of protein matrix embedded with many $<\sim 3 \mu \mathrm{m}$ coalesced lipid droplets were observed. In comparison, MHP after all dry heat temperatures studied, constantly produced irregularly sized meal fragments of 5 to $250 \mu \mathrm{m}$. Larger ( 5 to $15 \mu \mathrm{m})$ coalesced lipid droplets were located within wide internal crevices, created from dense aggregated protein matrix.

Table 2. Changes of protein molecular structure of canola meals produced at increasing barrel dry heat (20 to 180 ${ }^{\circ} \mathrm{C}$ ) with moist heat pressure (MHP)

\begin{tabular}{|c|c|c|c|c|c|c|c|c|c|c|c|c|c|c|}
\hline & \multirow{2}{*}{ MHP } & \multicolumn{8}{|c|}{ Barrel Dry Heat $\left({ }^{\circ} \mathrm{C}\right)$} & \multirow{2}{*}{ SEM } & \multirow{2}{*}{$P_{B T}$} & \multirow{2}{*}{$P_{M H P}$} & \multirow{2}{*}{$\mathrm{r}_{s}$} & \multirow{2}{*}{$R^{2}$} \\
\hline & & 20 & 60 & 80 & 100 & 120 & 140 & 160 & 180 & & & & & \\
\hline \multirow[t]{2}{*}{ Amide I } & - & 0.366 & 0.328 & 0.383 & 0.358 & 0.345 & 0.324 & 0.348 & 0.347 & 0.008 & NS & & -0.12 & 0.03 \\
\hline & + & 0.069 & 0.126 & 0.146 & 0.072 & 0.127 & 0.152 & 0.068 & 0.210 & 0.014 & NS & & 0.26 & 0.11 \\
\hline \multirow[t]{2}{*}{ Amide II } & - & 0.138 & 0.112 & 0.137 & 0.134 & 0.126 & 0.118 & 0.126 & 0.124 & 0.004 & NS & \multirow{2}{*}{$* *$} & -0.03 & 0.02 \\
\hline & + & 0.131 & 0.044 & 0.061 & 0.119 & 0.030 & 0.060 & 0.080 & 0.014 & 0.011 & NS & & -0.39 & 0.16 \\
\hline \multirow[t]{2}{*}{$\alpha$-helix } & - & 0.004 & 0.004 & 0.005 & 0.004 & 0.004 & 0.004 & 0.004 & 0.004 & 0.000 & $\mathrm{NS}$ & \multirow{2}{*}{$* *$} & -0.22 & 0.07 \\
\hline & + & 0.001 & 0.001 & 0.001 & 0.001 & 0.001 & 0.001 & 0.001 & 0.001 & 0.000 & NS & & -0.18 & 0.04 \\
\hline \multirow[t]{2}{*}{$\beta$-sheet } & - & 0.004 & 0.004 & 0.005 & 0.004 & 0.004 & 0.004 & 0.004 & 0.004 & 0.001 & $\mathrm{NS}$ & \multirow{2}{*}{$* *$} & -0.27 & 0.08 \\
\hline & + & 0.000 & 0.001 & 0.001 & 0.000 & 0.001 & 0.001 & 0.001 & 0.002 & 0.002 & NS & & 0.23 & 0.12 \\
\hline \multirow[t]{2}{*}{ Ratio of AI:AII } & - & 2.679 & 2.959 & 2.801 & 2.693 & 2.787 & 2.754 & 2.765 & 2.796 & 0.041 & $\mathrm{NS}$ & \multirow[t]{2}{*}{ * } & 0.08 & 0.01 \\
\hline & + & $0.562^{\mathrm{b}}$ & $5.786^{\mathrm{b}}$ & $8.174^{\mathrm{ab}}$ & $0.624^{\mathrm{b}}$ & $7.334^{\mathrm{ab}}$ & $7.915^{\mathrm{ab}}$ & $0.942^{\mathrm{b}}$ & $15.08^{\mathrm{a}}$ & 1.271 & $*$ & & 0.41 & 0.16 \\
\hline \multirow[t]{2}{*}{ Ratio of $\alpha: \beta$} & - & 1.034 & 1.067 & 1.043 & 1.207 & 1.048 & 1.011 & 1.052 & 1.059 & 0.006 & NS & \multirow{2}{*}{$* *$} & 0.10 & 0.02 \\
\hline & + & $9.804^{\mathrm{ab}}$ & $3.873^{\mathrm{abcd}}$ & $3.155^{\mathrm{bcd}}$ & $9.653^{\mathrm{ab}}$ & $2.113^{\text {bd }}$ & $6.810^{\mathrm{b}}$ & $6.836^{\mathrm{b}}$ & $0.564^{\mathrm{d}}$ & 0.893 & $*$ & & -0.27 & 0.11 \\
\hline \multirow[t]{2}{*}{ TPFR } & - & 0.686 & 0.674 & 0.710 & 0.714 & 0.666 & 0.647 & 0.667 & 0.645 & 0.011 & $\mathrm{NS}$ & & -0.31 & 0.10 \\
\hline & + & 0.547 & 0.574 & 0.553 & 0.510 & 0.535 & 0.554 & 0.503 & 0.560 & 0.009 & NS & & -0.02 & 0.02 \\
\hline
\end{tabular}

Note. $\mathrm{MHP}=$ moist heat pressure $\left(120^{\circ} \mathrm{C} 15 \mathrm{~min} 192 \mathrm{kPa}\right)$. Attenuated total reflectance-Fourier transform infrared spectrum absorbance units were analysed for protein molecular structure regions, as previously described by Samadi et al. (2013). The total protein fingerprint region (TPFR) ca. 1714 to $1480 \mathrm{~cm}^{-1}$ included amide I (AI area ca. 1714 to $1571 \mathrm{~cm}^{-1}$ ), amide II (AII area ca. 1572 to $1480 \mathrm{~cm}^{-1}$ ), $\alpha$-helix ( $\alpha$ peak centre height at ca. $1652 \mathrm{~cm}^{-1}$ with the baseline of ca. 1714 to $\left.1480 \mathrm{~cm}^{-1}\right)$ and $\beta$-sheet ( $\beta$ peak centre height at ca. $1630 \mathrm{~cm}^{-1}$ with the baseline of ca. 1714 to $1480 \mathrm{~cm}^{-1}$ ), ratio of amide I to II (AI:AII), and the ratio of $\alpha$-helix to $\beta$-sheet (height) $(\alpha: \beta)$. Means in rows with unlike superscripts differ $(P<0.05)$. SEM $=$ standard error of mean; $\mathrm{r}_{\mathrm{s}}=$ pair-wise Spearman correlation coefficient; $R^{2}=$ coefficient of determination; $P_{B T}=$ difference between barrel temperatures; ${ }^{* *} P<0.01 ;{ }^{*} P<0.05 ; \mathrm{NS}=$ not significant.

The effect of increasing dry heat temperature and application of MHP on resistance of canola meal to in vitro proteolytic digestion performed utilising CLSM is presented in Figure 2 (and Figure A6). Degradation around all sides of intact cotyledon cellular structure of meals at a dry heat temperature of 20 and $60^{\circ} \mathrm{C}$ was greater $(<\sim 75$ $\mu \mathrm{m})$ than at $80^{\circ} \mathrm{C}(<\sim 60 \mu \mathrm{m})$. At $20,60,80,160$, and $180{ }^{\circ} \mathrm{C}$, open shells of proteinaceous cellular wall surrounded the outer surface of meal fragments. From 100 to $140{ }^{\circ} \mathrm{C}$ minimal degradation was observed due to aggregated protein matrix $(<\sim 10 \mu \mathrm{m})$. The presence of fragments of detached protein matrix $<\sim 25 \mu \mathrm{m}$ decreased in size and frequency as dry heat temperature increased from 20 to $160{ }^{\circ} \mathrm{C}$. At 20,60 and $80{ }^{\circ} \mathrm{C}$, lipid bodies of increasing size $<\sim 2 \mu \mathrm{m},<20 \mu \mathrm{m}$ and $<\sim 30 \mu \mathrm{m}$ were present within cells, respectively. The presence of surface lipid bodies $<\sim 4 \mu \mathrm{m}$ was greatest at $100{ }^{\circ} \mathrm{C}$, and then similar between 120 to $180{ }^{\circ} \mathrm{C}$ dry heat temperatures. In vitro proteolytic degradation of cellular structure was less pronounced in all MHP meals. Meals expelled at 20 and $60^{\circ} \mathrm{C}$ with MHP, had wider crevices within the aggregated protein matrix than other dry heat temperatures. Similar levels of $<\sim 5 \mu \mathrm{m}$ surface lipid bodies and coalesced lipid droplets within crevices were evident in all MHP meals.

The effects of increasing dry heat temperature and application of MHP on meal surface morphology, utilising SEM, are presented in Figure 3 and (Figures A7 and A8). At 20 to $100{ }^{\circ} \mathrm{C}$, and 120 to $180^{\circ} \mathrm{C}$ the size of meal fragments varied from $5 \mu \mathrm{m}$ to $1 \mathrm{~mm}$, and from 5 to $500 \mu \mathrm{m}$, respectively. At 20 to $180{ }^{\circ} \mathrm{C}$, intact, irregular and complex surface and fragment structures were observed, and at $\geq 80$ and $\geq 120^{\circ} \mathrm{C}$ the surface meal became more rounded and then flattened, respectively. Proceeding in vitro proteolytic digestion, micrographs revealed surface 
structures resistant to proteolysis (Figures 3 and A8). Notably, at $\geq 120$ to $180{ }^{\circ} \mathrm{C}$ remaining surfaces were flattened in meals. At $\geq 100{ }^{\circ} \mathrm{C}$, the surface of MHP meals exhibited uniformly spaced crevices reminiscent collapsed cell wall structure.

Table 3. Changes in lipid related molecular structure of canola meals produced at increasing barrel dry heat (20 to $180^{\circ} \mathrm{C}$ ) with moist heat pressure (MHP)

\begin{tabular}{|c|c|c|c|c|c|c|c|c|c|c|c|c|c|c|}
\hline & \multirow{2}{*}{ MHP } & \multicolumn{8}{|c|}{ Barrel Dry Heat $\left({ }^{\circ} \mathrm{C}\right)$} & \multirow{2}{*}{ SEM } & \multirow{2}{*}{$P_{B T}$} & \multirow{2}{*}{$P_{M H P}$} & \multirow[b]{2}{*}{$\mathbf{r}_{s}$} & \multirow{2}{*}{$R^{2}$} \\
\hline & & 20 & 60 & 80 & 100 & 120 & 140 & 160 & 180 & & & & & \\
\hline \multirow[t]{2}{*}{ ULB } & - & $0.000^{\mathrm{c}}$ & $0.000^{\mathrm{c}}$ & $0.000^{\mathrm{c}}$ & $0.000^{\mathrm{c}}$ & 0.75 & $0.002^{\mathrm{bc}}$ & $0.004^{\mathrm{ab}}$ & $0.006^{\mathrm{a}}$ & 0.000 & $* *$ & \multirow{2}{*}{ NS } & 0.75 & 0.78 \\
\hline & + & $0.000^{\mathrm{d}}$ & $0.001^{\mathrm{d}}$ & $0.000^{\mathrm{d}}$ & $0.000^{\mathrm{d}}$ & 0.80 & $0.003^{\mathrm{c}}$ & $0.006^{\mathrm{ab}}$ & $0.008^{\mathrm{a}}$ & 0.000 & $* *$ & & 0.80 & 0.89 \\
\hline \multirow[t]{2}{*}{ LCCE } & - & $0.002^{\mathrm{b}}$ & $0.002^{\mathrm{b}}$ & $0.002^{\mathrm{b}}$ & $0.002^{\mathrm{b}}$ & 0.70 & $0.034^{\mathrm{a}}$ & $0.046^{\mathrm{a}}$ & $0.053^{\mathrm{a}}$ & 0.005 & $* *$ & \multirow{2}{*}{ NS } & 0.70 & 0.79 \\
\hline & + & $0.003^{\mathrm{d}}$ & $0.005^{\mathrm{d}}$ & $0.004^{\mathrm{d}}$ & $0.004^{\mathrm{d}}$ & 0.77 & $0.026^{\mathrm{c}}$ & $0.047^{\mathrm{b}}$ & $0.058^{\mathrm{a}}$ & 0.005 & $* *$ & & 0.77 & 0.87 \\
\hline \multirow[t]{2}{*}{$\mathrm{CH}_{3 \mathrm{AS}}$} & - & $0.001^{\mathrm{c}}$ & $0.001^{\mathrm{c}}$ & $0.001^{\mathrm{c}}$ & $0.001^{\mathrm{c}}$ & 0.72 & $0.018^{\mathrm{b}}$ & $0.028^{\mathrm{ab}}$ & $0.032^{\mathrm{a}}$ & 0.003 & $* *$ & \multirow{2}{*}{ NS } & 0.72 & 0.82 \\
\hline & + & $0.001^{\mathrm{d}}$ & $0.002^{\mathrm{d}}$ & $0.002^{\mathrm{d}}$ & $0.002^{\mathrm{d}}$ & 0.78 & $0.013^{\mathrm{c}}$ & $0.024^{\mathrm{ab}}$ & $0.031^{\mathrm{a}}$ & 0.002 & $* *$ & & 0.78 & 0.88 \\
\hline \multirow[t]{2}{*}{$\mathrm{CH}_{2 \mathrm{AS}}$} & - & $0.003^{\mathrm{c}}$ & $0.003^{\mathrm{c}}$ & $0.003^{\mathrm{c}}$ & $0.003^{\mathrm{c}}$ & 0.68 & $0.067^{\mathrm{b}}$ & $0.066^{\mathrm{ab}}$ & $0.072^{\mathrm{a}}$ & 0.007 & $* *$ & \multirow{2}{*}{ NS } & 0.68 & 0.80 \\
\hline & + & $0.003^{\mathrm{c}}$ & $0.005^{\mathrm{c}}$ & $0.004^{c}$ & $0.004^{c}$ & 0.78 & $0.031^{\mathrm{b}}$ & $0.018^{\mathrm{a}}$ & $0.025^{\mathrm{a}}$ & 0.006 & $* *$ & & 0.78 & 0.87 \\
\hline \multirow[t]{2}{*}{$\mathrm{CH}_{3 \mathrm{~S}}$} & - & $0.001^{\mathrm{d}}$ & $0.001^{\text {cd }}$ & $0.001^{\mathrm{cd}}$ & $0.001^{\mathrm{d}}$ & 0.72 & $0.015^{\mathrm{c}}$ & $0.023^{\mathrm{b}}$ & $0.025^{\mathrm{a}}$ & 0.002 & $* *$ & \multirow{2}{*}{ NS } & 0.72 & 0.81 \\
\hline & + & $0.001^{\mathrm{b}}$ & $0.002^{\mathrm{b}}$ & $0.001^{\mathrm{b}}$ & $0.001^{\mathrm{b}}$ & 0.80 & $0.008^{\mathrm{a}}$ & $0.018^{\mathrm{a}}$ & $0.025^{\mathrm{a}}$ & 0.002 & $* *$ & & 0.80 & 0.89 \\
\hline \multirow[t]{2}{*}{$\mathrm{CH}_{2 \mathrm{~S}}$} & - & $0.002^{\mathrm{b}}$ & $0.002^{\mathrm{b}}$ & $0.002^{\mathrm{b}}$ & $0.002^{\mathrm{b}}$ & 0.70 & $0.027^{\mathrm{a}}$ & $0.038^{\mathrm{a}}$ & $0.042^{\mathrm{a}}$ & 0.005 & $* *$ & \multirow{2}{*}{ NS } & 0.70 & 0.80 \\
\hline & + & $0.002^{\mathrm{d}}$ & $0.003^{\mathrm{d}}$ & $0.003^{\mathrm{d}}$ & $0.003^{\mathrm{d}}$ & 0.77 & $0.020^{\mathrm{c}}$ & $0.035^{\mathrm{b}}$ & $0.043^{\mathrm{a}}$ & 0.005 & $* *$ & & 0.77 & 0.87 \\
\hline \multirow[t]{2}{*}{ Ratio of $\mathrm{CH}_{3}: \mathrm{CH}_{2 \mathrm{AS}}$} & - & 0.412 & 0.419 & 0.419 & 0.415 & 0.24 & 0.404 & 0.421 & 0.440 & 0.004 & NS & \multirow{2}{*}{ NS } & 0.24 & 0.15 \\
\hline & + & 0.380 & 0.414 & 0.422 & 0.404 & 0.49 & 0.415 & 0.413 & 0.445 & 0.005 & NS & & 0.49 & 0.29 \\
\hline \multirow[t]{2}{*}{ Ratio of $\mathrm{CH}_{3}: \mathrm{CH}_{2 \mathrm{~S}}$} & - & 0.573 & 0.563 & 0.575 & 0.597 & 0.07 & 0.565 & 0.591 & 0.578 & 0.005 & NS & \multirow{2}{*}{$* *$} & 0.07 & 0.02 \\
\hline & + & 0.407 & 0.471 & 0.506 & 0.439 & 0.55 & 0.471 & 0.493 & 0.584 & 0.016 & NS & & 0.55 & 0.25 \\
\hline
\end{tabular}

Note. $\mathrm{MHP}=$ moist heat pressure $\left(120^{\circ} \mathrm{C} 15 \mathrm{~min} 192 \mathrm{kPa}\right)$. Attenuated total reflectance-Fourier transform infrared spectrum absorbance units were analysed for lipid related molecular structure regions, as previously described by Samadi and $\mathrm{Yu}$ (2012). Regions included the lipid unsaturated band $\mathrm{C}=\mathrm{C}$ (ULB, peak height centre at ca. 3007 $\mathrm{cm}^{-1}$ ), carbonyl $\mathrm{C}=\mathrm{O}$ ester stretching band (LCCE, baseline ca. 1789 to $1701 \mathrm{~cm}^{-1}$ with peak height ca. $1744 \mathrm{~cm}^{-1}$ ), $\mathrm{CH}_{3}$ asymmetric $\left(\mathrm{CH}_{3 \mathrm{~A}}\right.$ ca. 2988 to $2951 \mathrm{~cm}^{-1}$ with peak height centre at ca. $\left.2955 \mathrm{~cm}^{-1}\right), \mathrm{CH}_{2}$ asymmetric $\left(\mathrm{CH}_{2 \mathrm{~A}} \mathrm{ca}\right.$. 2951 to $2882 \mathrm{~cm}^{-1}$ with peak height centre at ca. $\left.2922 \mathrm{~cm}^{-1}\right), \mathrm{CH}_{3}$ symmetric $\left(\mathrm{CH}_{3 \mathrm{~S}} \mathrm{ca} .2882\right.$ to $2868 \mathrm{~cm}^{-1}$ with peak height centre at ca. $\left.2872 \mathrm{~cm}^{-1}\right)$ and $\mathrm{CH}_{2}$ symmetric $\left(\mathrm{CH}_{2 \mathrm{~S}} \mathrm{ca} .2868\right.$ to $2790 \mathrm{~cm}^{-1}$ with peak height centre at ca. 2852 $\left.\mathrm{cm}^{-1}\right)$. Means in rows with unlike superscripts differ $(P<0.05)$. SEM = standard error of mean; $\mathrm{r}_{\mathrm{s}}=$ pair-wise Spearman correlation coefficient; $R^{2}=$ coefficient of determination; $P_{B T}=$ difference between barrel temperatures; $* * P<0.01 ; * P<0.05 ; \mathrm{NS}=$ not significant.

\section{Discussion}

In this study, the effects of barrel dry heat and MHP on MRP formation and structural characteristics of canola meals were investigated. Colorimetry values were similar to those reported for canola meal by El-Kadiri et al. (2013). Meal lightness and yellowness decreased with dry heat temperature. The latter is reflective of the formation of blue pigments (early-MRP) through xylose-glycine reactions (Ames, 1992). Application of MHP darkened, reddened and also promoted the formation of blue-pigments in the meal. A reduction of Abs $294 \mathrm{~nm}$ and increase in darkness and BI implied MHP further progressed intermediate Maillard reactions to late. The AOF (2004) reported darker meal was beneficial quality for dairy; however, Classen et al. (2005) reported early reactions causing colour change negatively impact AA digestibility by poultry and thus are unfavourable for monogastric digestion. 


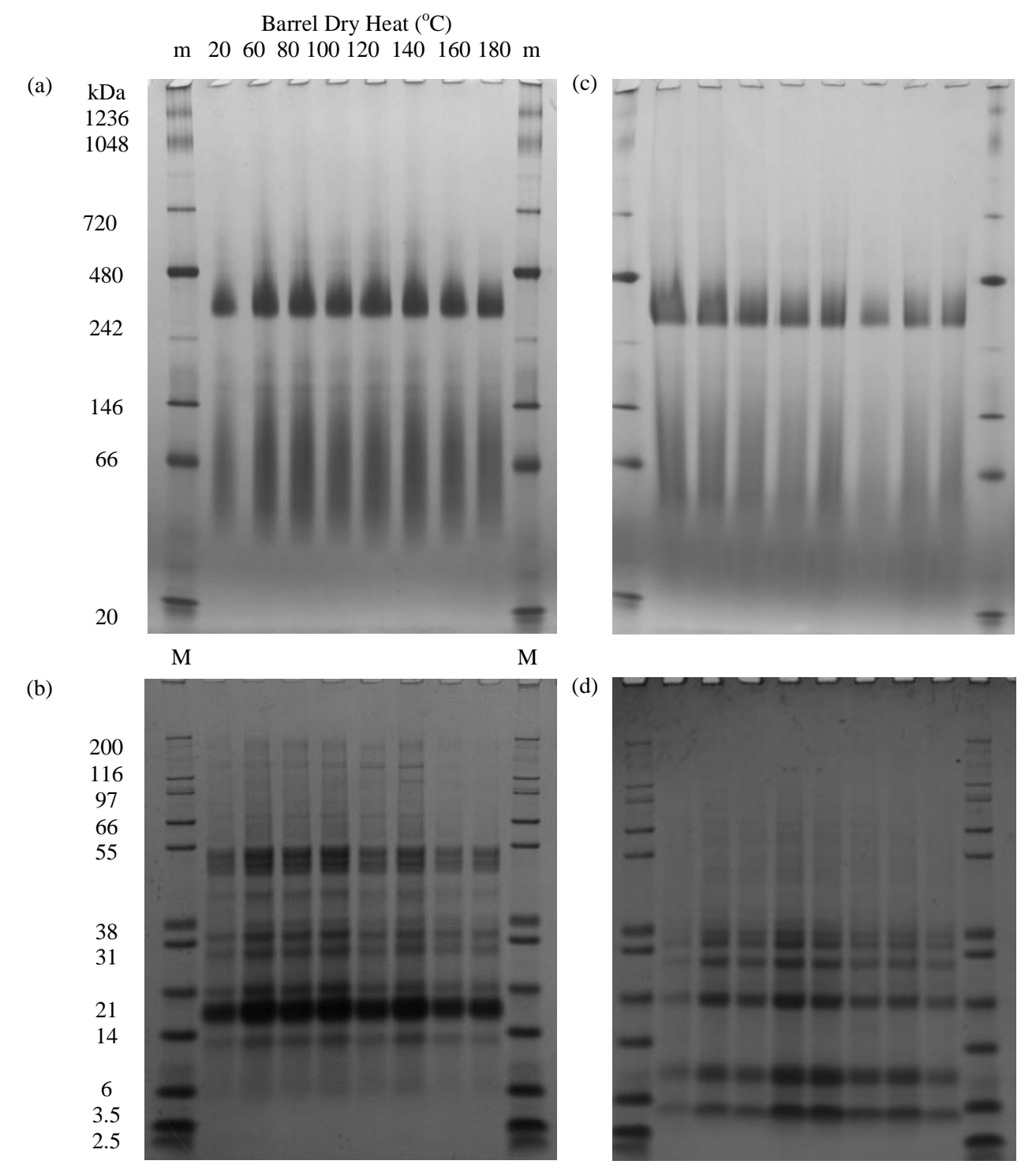

Figure 1. Representative native gel electrophoresis (a, c) and SDS-PAGE (b, d) protein profile of canola meal produced at increasing barrel dry heat $\left(20\right.$ to $\left.180^{\circ} \mathrm{C}\right)$ revealed with coomassie blue stain. A $30 \mu \mathrm{g}$ aliquot of each sample was loaded per well. Borate-phosphate buffer soluble (b, d) and water soluble (a, c) protein. Non-reduced (b), reduced (d). A $5 \mu \mathrm{L}$ aliquot of Mark 12 Unstained Protein Standard (M) or NativeMark unstained protein standard (m) was loaded

The $\mathrm{pH}$ of meal suspensions was more basic than the $\mathrm{pH}$ of 5.2 reported by DairyOne (2016). An increase of acidity in the MHP meals suggests treatment induced Maillard reaction protein-sugar covalent bond formation. 
(a)

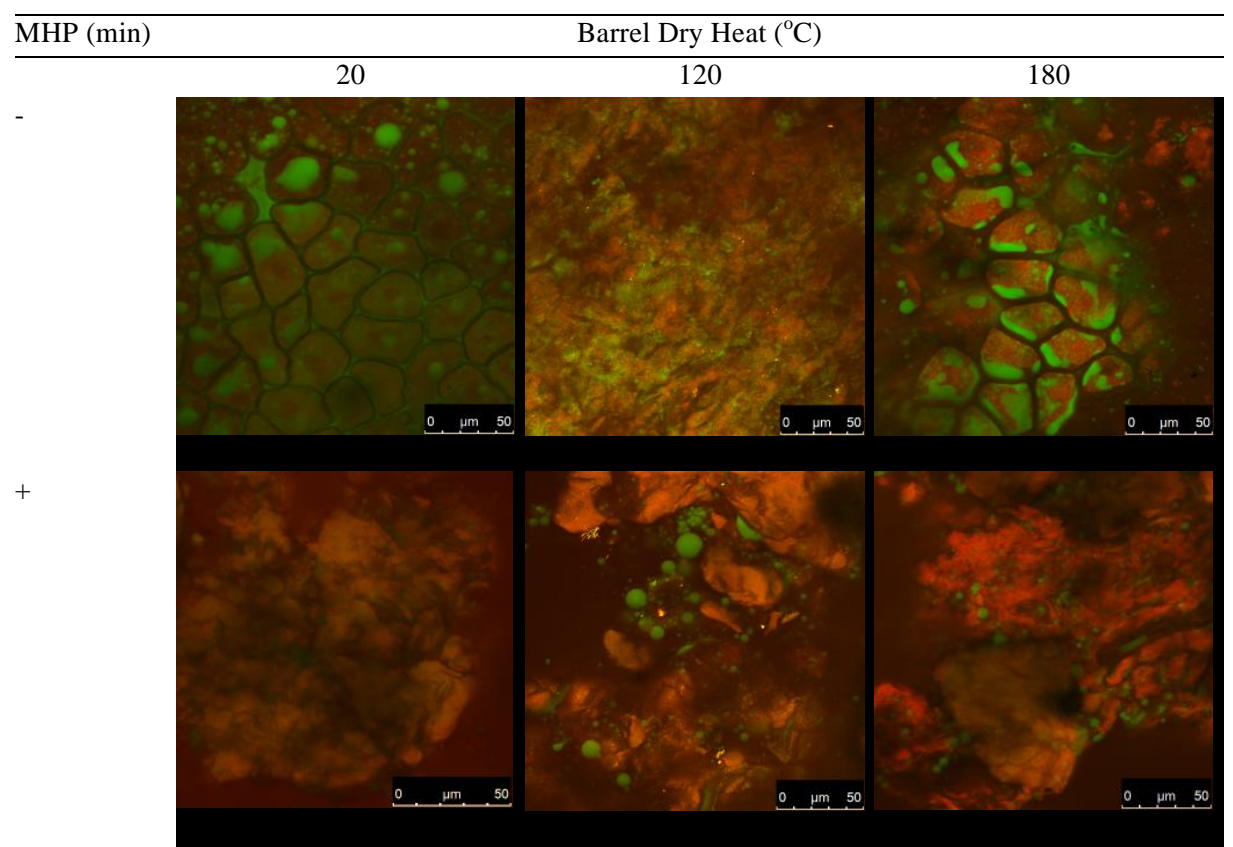

(b)

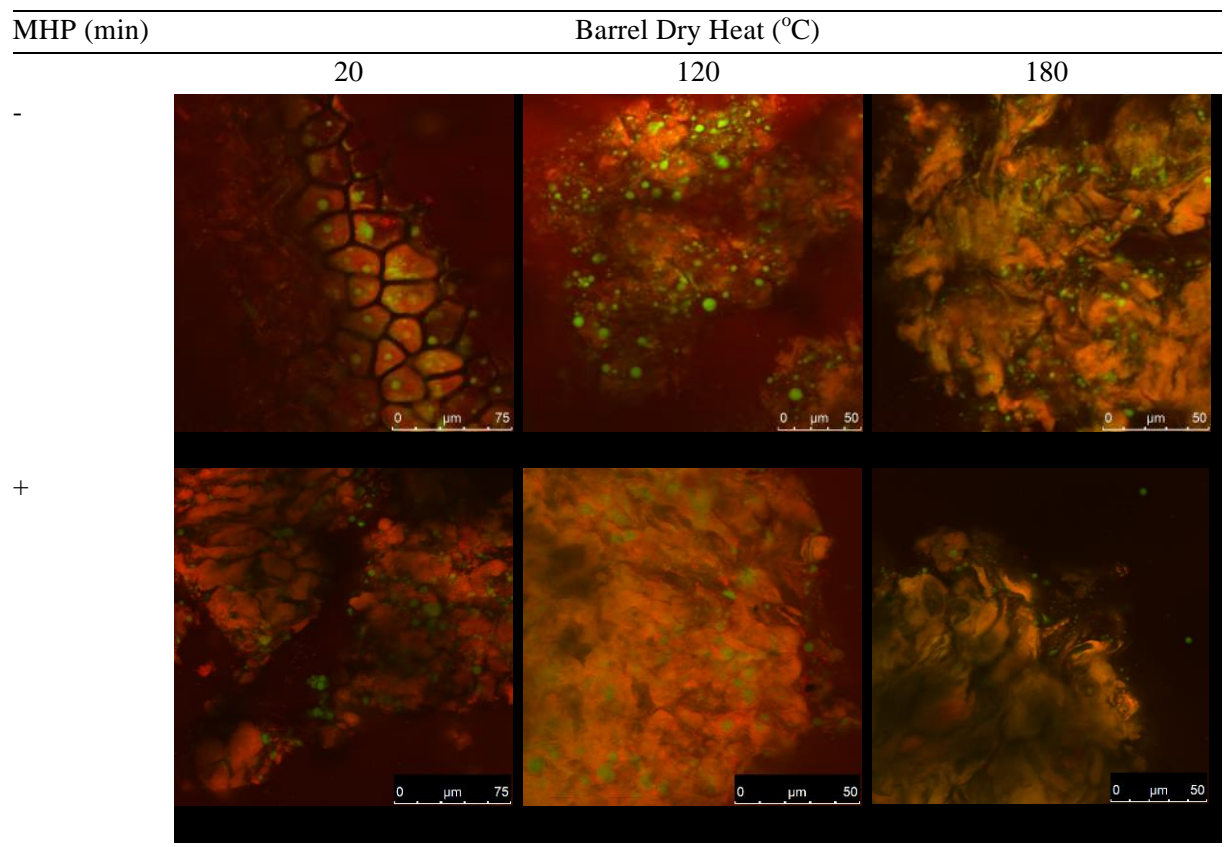

Figure 2. Representative confocal laser scanning micrographs of canola produced at increasing barrel dry heat (20 to $180^{\circ} \mathrm{C}$ ) with moist heat pressure (MHP) treatment $\left(\mathrm{a}, 120^{\circ} \mathrm{C}, 15 \mathrm{~min}, 192 \mathrm{kPa}\right)$ and proteolytic digestion (b).

Protein is stained red with Nile Blue dye, and lipid is stained green with Fast Green FCF dye. Scale bars correspond to 75 or $50 \mu \mathrm{M}$ 
(a)

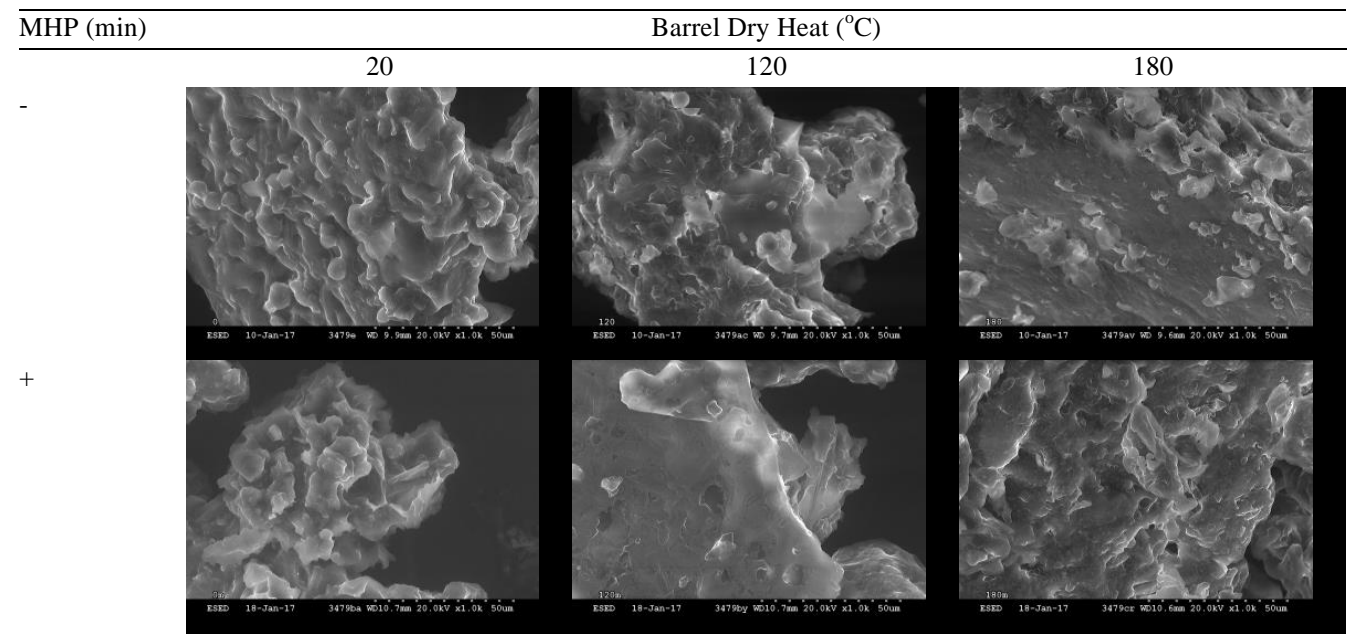

(b)

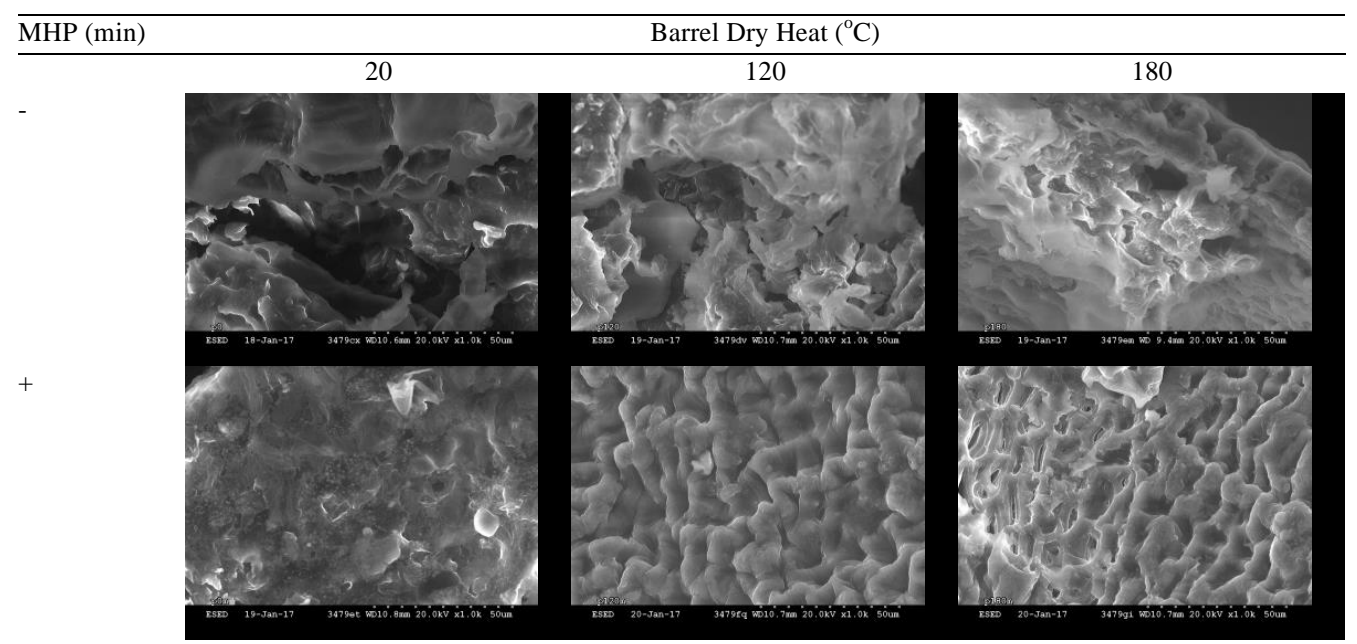

Figure 3. Representative scanning electron photomicrographs of canola produced at increasing barrel dry heat $\left(20\right.$ to $180{ }^{\circ} \mathrm{C}$ ) with moist heat pressure (MHP) treatment $\left(\mathrm{a}, 120{ }^{\circ} \mathrm{C}, 15 \mathrm{~min}, 192 \mathrm{kPa}\right.$ ) and post proteolytic digestion (b). Images were taken with $\times 1$.0k resolution

Alternatively, Liu et al. (2014) theorised that the consumption of amino groups during the Maillard reaction may result in acid formation. A reduction of $\mathrm{Abs}_{294 \mathrm{~nm}}$ and increase in darkness and BI suggests MHP further progressed intermediate to late Maillard reactions. Interrelationships of protein $S o$ and enzyme-attachment are well established; however, the effect of processing conditions on canola meal protein $S o$ and ruminal degradability are not well understood. Positive correlation of canola meal suspension So and dry heat temperature suggests induction of protein unfolding and denaturation (Perera et al., 2016) and aggregation (Davis \& Williams 1998). Folawiyo and Apenten (1997) reported heat treatment of rapeseed napin induced irreversible changes in $S o$ at $90^{\circ} \mathrm{C}$. At 20 to $120^{\circ} \mathrm{C}$ and 140 to $180{ }^{\circ} \mathrm{C}$, MHP meal shifted $S o$ from low to high relative to control meal, to suggest at low and moderate processing temperatures MHP induces protein folding events promoting surface hydrophilic conformation; however, at 140 to $180{ }^{\circ} \mathrm{C}$ modifications of turning of side-chains outwards, commonly associated with protein unfolding, loss of $2^{\circ}$ and $3^{\circ}$ structure, scrambling of disulphide bonds, and formation of irreversible protein aggregates contribute to increases in protein hydrophobicity (Davis \& Williams, 1998).

Increasing dry heat temperature had no impact on molecular protein structure characteristics, except the ratios of amide I to II and $\alpha$-helix to $\beta$-sheet in MHP meal. According to Peng et al. (2014), an increase of amide I to II at $180^{\circ} \mathrm{C}$ was suggestive of increased rumen degradable $\mathrm{CP}$, whereas a decrease in $\alpha$-helix to $\beta$-sheet at $\geq 120^{\circ} \mathrm{C}$ would infer increases in intestinal digestible RUP and total digestible CP. Treatment with MHP induced 
noticeable changes in all molecular protein structure characteristics studied. When Samadi et al. (2013) applied dry heat $\left(120^{\circ} \mathrm{C} 1 \mathrm{~h}\right)$ to canola seed a similar increase in $\alpha$-helix: $\beta$-sheet was observed. Yu (2013) similarly observed a higher $\alpha$-helix: $\beta$-sheet spectral intensity ratio in canola tissue treated with MHP, than dry heat treatment and raw tissue controls. According to correlations published by Samadi et al. (2013), the findings imply MHP increases rumen degradable CP, decreases intestinal digestible RUP and total digestible CP. Samadi and $\mathrm{Yu}$ (2012) reported dry heat and MHP had no effect on lipid molecular structure in canola meal; however, in this study distinct differences in lipid-related functional groups between dry heat temperatures and with MHP were observed.

Similar total and water soluble protein polypeptide bands for expeller with MHP meals were observed in previous reports for B. napus meal by Wanasundara and McIntosh (2013), and Wu and Muir (2008). In non-reduced conditions, typical storage protein polypeptide bandings were observed for $11 \mathrm{~S}$ globulin (cruciferin) i.e. trimer $(\sim 177)$, dimer $(\sim 118)$ (Perera et al., 2016), procruciferin subunits $(73.5,76.8), \alpha-(26.7,28.5,37.1)$, $\beta-(18.3,21.1,22.9)$ (Wanasundara, 2011), and monomer with intact disulfide linkages (41 to 55) (Perera et al., 2016); and $2 \mathrm{~S}$ albumin (napin) i.e. dimer (27.5) and monomer (14) (Wu \& Muir, 2008). Under reduced conditions, involvement of disulphide bonds was suggested by disappearance of polypeptides for cruciferin i.e. trimer, dimer, and monomer with intact disulphide bands (41 to 55); and, napin (14); and, the associated formation of polypeptide bands for cruciferin i.e. 9.6 to 32.0 range, and for napin i.e. light 4 and heavy 9 . Polypeptide bands present under non- and reduced conditions at 18 to 25,27 , or 39 or 41 likely corresponded to known oil binding proteins of oleosins, caleosins or steroleosins, respectively (Wanasundara et al., 2016). Under non-reducing conditions, SDS-PAGE of soluble protein revealed at dry heat temperatures of 160 and $180{ }^{\circ} \mathrm{C}$ high MW polypeptides were absent, suggesting the formation of insoluble higher MW polypeptides and protein denaturation. Treatment with MHP hindered protein extraction and reduced solubility of canola meal polypeptides larger than $\sim 40 \mathrm{kDa}$. Native gel electrophoresis affirmed cruciferin solubility reduced with increasing dry heat. Progressive dry heat-induced changes in the structure of cruciferin were similarly reported by Perera et al. (2016). Reduced ability to extract protein from MHP meal suggests the formation of irreversible bonds and formation of insoluble high MW protein aggregates in canola meal treated under these conditions. Perera et al. (2016) reported thermal-stability of napin. Native 20 to $146 \mathrm{kDa}$ protein band smearing was indicative of heat-induced modifications of napin at all dry heat temperatures. Kennelly (1996) theorised dry heating of oilseed denatured protein matrix surrounding fat droplets, to protect dietary fatty acids from biohydrogenation by ruminal bacteria. Due to the diverse composition of rapeseed meal proteins temperatures and time-points of denaturation and aggregations vary (Folawiyo \& Apenten, 1997). In this study, dry heat temperatures of $\geq 80^{\circ} \mathrm{C}$ induced protein matrix formation functioning to encapsulate lipid and release lipid at $100^{\circ} \mathrm{C}$. These events may respectively be attributed to known denaturation temperatures for canola meal protein $\left(83.9^{\circ} \mathrm{C}\right)$, cruciferin $\left(90.7^{\circ} \mathrm{C}\right)$, and napin proteins $\left(110^{\circ} \mathrm{C}\right)$, as reported by $\mathrm{Wu}$ and Muir $(2008)$. Formation of aggregated protein matrix seemed to improve resistance to enzymatic degradation from 100 to $140{ }^{\circ} \mathrm{C}$. With respect to expeller meal structural organisation, application of MHP resulted in the consistent formation of meal fragments of densely aggregated heterogeneous protein matrix, containing crevices where coalesced lipid droplets resided. Treatment with MHP reduced in vitro proteolytic degradation of the cellular structure relative to the control meal, reaffirming observed decreases in in vitro ruminal degradability. Further analysis of surface morphology by SEM, revealed distinct structural differences of rounding and flattening at 80 and $120{ }^{\circ} \mathrm{C}$ corresponded to denaturation points published by $\mathrm{Wu}$ and Muir (2008) for isolated canola meal proteins $\left(83^{\circ} \mathrm{C}\right)$ and napin $\left(109^{\circ} \mathrm{C}\right)$. Reduction in fragment size at $120^{\circ} \mathrm{C}$ may additionally be attributed to denaturation of napin. Reduced fragment size may increase enzyme accessibility and proteolysis within the rumen.

Alterations in canola meal structural characteristics induced by MHP may affect ruminal degradation and supply of protein and AA for ruminant production. To the authors' best knowledge these are first reports of the microscopic structure, and protein and lipid characteristics of cold-press, expeller and moist heat pressure treatment canola meals. These findings will likely benefit producers of canola meal by further detailing the effects of barrel dry heat temperature and MHP on MRP formation and structural characteristics of canola meal. Further knowledge of the formation of heat-damage protein during processing of canola meal will enhance ration formulations, and of microscopic characteristics that favour resistance to enzymatic degradation will assist production of canola meal with improved protein value for ruminants.

\section{Acknowledgements}

The research is financed by the Australian Research Council Industrial Transformation Training Centre for Functional Grains program: Project 100737. 
The authors thank the CSIRO Agriculture and Food for the provision of facilities, and personnel for their interest and assistance during the completion of the study. Special thanks also to industry partner MSM Milling Pty Ltd for their valuable knowledge, assistance, and source of canola. The authors thank Dr Asgar Farahnaky and Colin Veitch for their advice, expertise, and assistance.

\section{References}

Ajandouz, E. H., Tchiakpe, L. S., Dalle Ore, F., Benajiba, A., \& Puigserver, A. (2001). Effects of pH on caramelization and Maillard reaction kinetics in fructose-lysine model systems. Journal of Food Science, 66(7), 926-931. https://doi.org/10.1111/j.1365-2621.2001.tb08213.x

Ames, J. M. (1992). Chapter 4: The Maillard Reaction. Biochemistry of Food Proteins (1st ed., pp. 99-153). Springer, Boston, MA, USA. https://doi.org/10.1007/978-1-4684-9895-0_4

AOF. (2004). Canola Meal. Limitations and Opportunities. Wagga Wagga, NSW, Australia. Retrieved from http://www.australianoilseeds.com/_data/assets/pdf_file/0011/1271/AOF_Canola_Meal_Report-Limitatio ns__and__Opportunities_2004.pdf

Bal, L. M., Kar, A., Satya, S., \& Naik, S. N. (2011). Kinetics of colour change of bamboo shoot slices during microwave drying. International Journal of Food Science + Technology, 46, 827-833. https://doi.org/ 10.1111/j.1365-2621.2011.02553.x

Classen, H. L., Newkirk, R. K., \& Maenz, D. D. (2005). Effects of conventional and novel processing on the feed value of canola meal for poultry. Retrieved from http://www.thepoultrysite.com/articles/307/effects-ofconventional-and-novel-processing-on-the-feed-value-of-canola-meal-for-poultry/

DairyOne. (2016). Interactive Feed Composition Library Accumulated Crop Years 5/1/2000-4/30/2016. Retrieved from http://www.dairyone.com/analytical-services/feed-and-forage/feed-composition-library/

Davis, P. J., \& Williams, S. C. (1998). Protein modification by thermal processing. Allergy, 53(102-105). https://doi.org/10.1111/j.1398-9995.1998.tb04975.x

El-Kadiri, I., Khelifi, M., \& Aider, M. (2013). The effect of hydrogen peroxide bleaching of canola meal on product colour, dry matter and protein extractability and molecular weight profile. International Journal of Food Science + Technology, 48, 1071-1085. https://doi.org/10.1111/ijfs. 12065

Folawiyo, Y. L., \& Apenten, R. K. O. (1997). The effect of heat- and acid-treatment on the structure of rapeseed albumin (napin). Food Chem., 58, 237-243. https://doi.org/10.1016/S0308-8146(96)00221-X

He, M. L., Gibb, D., McKinnon, J. J., \& McAllister, T. A. (2013). Effect of high dietary levels of canola meal on growth performance, carcass quality and meat fatty acid profiles of feedlot cattle. Canadian Journal of Animal Science, 93(2), 269-280. https://doi.org/10.4141/cjas2012-090

Heim, R. A. L., \& Krebs, G. L. (2018). Effect of dry heat temperature and moist heat pressure on canola meal for ruminant utilisation. Part I. Nutritional, protein solubility and degradability characteristics. Journal of Agricultural Science, 10(8).

Jha, R., Woyengo, T. A., Li, J., Bedford, M. R., Vasanthan, T., \& Zijlstra, T. R. (2015). Enzymes enhance degradation of the fiber-starch-protein matrix of distillers dried grains with solubles as revealed by a porcine in vitro fermentation model and microscopy. Journal of Animal Science, 93, 1039-1051. https://doi.org/10.2527/jas.2014-7910

Kennelly, J. J. (1996). The fatty acid composition of milk fat as influenced by feeding oilseeds. Animal Feed Science Technology, 60(3), 137-152. https://doi.org/10.1016/0377-8401(96)00973-X

Leming, R., \& Lember, A. (2005). Chemical composition of expeller extracted and cold-pressed canola meal. Journal of Agricultural Sciences, 16, 103-109. https://doi.org/10.17605/OSF.IO/BR749

Liu, Q., Ling, J., Kong, B., Li, P., \& Xia, X. (2014). Physiochemical and antioxidant properties of Maillard reaction products formed by heating whey protein isolate and reducing sugars. International Journal of Dairy Technology, 67(2), 220-228. https://doi.org/10.1111/1471-0307.12110

Lopez, S. (2005). In vitro and in situ techniques for estimating digestibility (2nd ed., p. 4). CABI Publishing, Wallingford, Oxfordshire, UK.

Mauron, J. (1990). Influence of processing on protein quality. Journal of Nutritional Science and Vitaminology, 36(Suppl. 1), S57-S69. https://doi.org/10.3177/jnsv.36.4-SupplementI_S57 
Nakai, S. (2001). Measurement of Protein Hydrophobicity. Current Protocols in Food Analytical Chemistry. John Wiley \& Sons, Inc.

Newkirk, R. W. (2009). Canola Meal: Feed Industry Guide (4th ed., pp. 1-47). Canadian International Grains Institute, Winnipeg, MB, Canada. Retrieved from https://cigi.ca/wp-content/uploads/2011/12/2009-Canola_ Guide.pdf

Peng, Q., Khana, N. A., Wang, Z., \& Yu, P. (2014). Relationship of feeds protein structural makeup in common Prairie feeds with protein solubility, in situ ruminal degradation and intestinal digestibility. Animal Feed Science Technology, 194, 58-70. https://doi.org/10.1016/j.anifeedsci.2014.05.004

Perera, S., McIntosh, T., \& Wanasundara, J. (2016). Structural properties of cruciferin and napin of Brassica napus (canola) show distinct responses to changes in $\mathrm{pH}$ and temperature. Plants, 5(3), 36. https://doi.org/ 10.3390/plants5030036

Ross, D. A., Gutierrez-Botero, M., \& Van Amburgh, M. E. (2013). Refinement of an in vitro assay to evaluate intestinal protein digestability in ruminants. Paper presented at the Cornell Nutrition Conference for Feed Manufacturers, East Syracure, NY, USA.

Samadi, S. A., \& Yu, P. (2012). Response of lipid related molecular structure to wet and dry heating in canola tissue. Spectrochimica Acta Part A: Molecular and Biomolecular Spectroscopy, 90, 63-71. https://doi.org/ 10.1016/j.saa.2011.12.045

Samadi, S. A., Theodoridou, K., \& Yu, P. (2013). Detect the sensitivity and response of protein molecular structure of whole canola seed (yellow and brown) to different heat processing methods and relation to protein utilization and availability using ATR-FT/IR molecular spectroscopy with chemometrics. Spectrochimica Acta Part A: Molecular And Biomolecular Spectroscopy, 105, 304-313. https://doi.org/ 10.1016/j.saa.2012.11.096

Sánchez, J. M., \& Claypool, D. W. (1983). Canola meal as a protein supplement in dairy rations. Journal of Dairy Science, 66(1), 80-85. https://doi.org/10.3168/jds.S0022-0302(83)81756-1

Santos, J. E. P. (2011). Chapter 5: Nutritional Management of Lactating Dairy Cows. Dairy Production Medicine (1st ed., pp. 33-72). John Wiley \& Sons, Inc. http://doi.org/10.1002/9780470960554.ch5

Theodoridou, K., \& Yu, P. (2013). Application potential of ATR-FT/IR molecular spectroscopy in animal nutrition: revelation of protein molecular structures of canola meal and presscake, as affected by heat-processing methods, in relationship with their protein digestive behavior and utilization for dairy cattle. Journal of Agricultural Food Chemistry, 61(23), 5449-5458. https://doi.org/10.1021/jf400301y

Wanasundara, J. P. D. (2011). Proteins of Brassicaceae oilseeds and their potential as a plant protein source. Critical Reviews in Food Science and Nutrition, 51, 635-677. https://doi.org/10.1080/10408391003749942

Wanasundara, J. P. D., \& McIntosh, T. C. (2013). United States Patent No. US 8,557,963 B2. Online: United States Patent.

Wanasundara, J. P. D., McIntosh, T. C., Perera, S. P., \& Withana-Gamage, T. S. (2016). How might oilseeds help meet the protein challenge? Canola/rapeseed protein-functionality and nutrition. Oilseeds \& Fats Crops and Lipids, 23(4). https://doi.org/10.1051/ocl/2016028

White, C. L., \& Ashes, J. R. (1999). A review of methods for assessing the protein value of grain fed to ruminants. Australian Journal of Agricultural Research, 50, 855-869. https://doi.org/10.1071/AR98171

Williams, L. M., Block, H. C., Christensen, D. A., Racz, V., Ataku, K., Wildeman, B., \& McKinnon, J. J. (2008). Effect of feeding a processed barley/canola meal pellet on performance and carcass quality of feedlot steers. Canadian Journal of Animal Science, 88(4), 667-676. https://doi.org/10.4141/CJAS08053

Wu, J., \& Muir, A. D. (2008). Comparative structural, emulsifying, and biological properties of 2 major canola proteins, cruciferin and napin. Journal of Food Science, 73(3), C210-C216. https://doi.org/10.1111/ j.1750-3841.2008.00675.x

Yiu, S. H., Altosaar, I., \& Fulcher, R. G. (1983). The effects of commercial processing on the structure and microchemical organization of rapeseed. Journal of Food Structure, 2(2), Article 7.

Yu, P. (2013). Visualizing tissue molecular structure of a black type of canola (Brassica) seed with a thick seed coat after heat-related processing in a chemical way. Journal of Agricultural Food Chemistry, 61(7), 1471-1476. https://doi.org/10.1021/jf305207p 
Zhang, Z. M., Chen, S. F., Liang, Y. Z., Liu, Z. X., Zhang, Q. M., Ding, L. X., ... Zhouc, H. (2009). An intelligent background-correction algorithm for highly fluorescent samples in Raman spectroscopy. Journal of Raman Spectroscopy, 4l(6). https://doi.org/10.1002/jrs.2500

\section{Appendix A}

Table A1. Linear and polynomial equations to describe the effect of increasing barrel dry heat $\left(20\right.$ to $\left.180{ }^{\circ} \mathrm{C}\right)$ and moist heat pressure on Maillard Reaction product formation and structural characteristics of canola meals

\begin{tabular}{|c|c|c|}
\hline & MHP & Equation \\
\hline \multirow[t]{2}{*}{$b^{*}$} & - & $Y=15.63783-0.0186 x$ \\
\hline & + & $Y=7.60343-0.01269 x$ \\
\hline \multirow[t]{2}{*}{$L^{*}$} & - & $Y=62.34139-0.0337 x$ \\
\hline & + & $\mathrm{Y}=51.2279-0.01357 \mathrm{x}$ \\
\hline BI & - & $Y=66.57351+0.06478 x$ \\
\hline $\mathrm{pH}$ & + & $Y=6.43583-0.00128 x+6.09127 \times 10^{-6} x^{2}$ \\
\hline \multirow[t]{2}{*}{ So $(\%$ of soluble $\mathrm{CP})$} & - & $\mathrm{Y}=3.82892+0.00727 \mathrm{x}$ \\
\hline & + & $Y=3.17769-0.01949 x+2.30458 \times 10^{-4} x^{2}$ \\
\hline \multirow[t]{2}{*}{ ULB } & - & $Y=0.00156-6.15788 \times 10^{-5} \mathrm{x}+4.80073 \times 10^{-7} \mathrm{x}^{2}$ \\
\hline & + & $Y=0.00211-7.70111 \times 10^{-5} \mathrm{x}+6.15442 \times 10^{-7} \mathrm{x}^{2}$ \\
\hline \multirow[t]{2}{*}{ LCCE } & - & $Y=0.01468-6.11098 \times 10^{-4} \mathrm{x}+5.39912 \times 10^{-6} \mathrm{x}^{2}$ \\
\hline & + & $Y=0.01728-6.20985 \times 10^{-4} \mathrm{x}+5.13111 \times 10^{-6} \mathrm{x}^{2}$ \\
\hline \multirow[t]{2}{*}{$\mathrm{CH}_{3 \mathrm{AS}}$} & - & $\mathrm{Y}=0.00676-2.78077 \times 10^{-4} \mathrm{x}+2.39645 \times 10^{-6} \mathrm{x}^{2}$ \\
\hline & + & $\mathrm{Y}=0.00777-2.80962 \times 10^{-4} \mathrm{x}+2.27938 \times 10^{-6} \mathrm{x}^{2}$ \\
\hline \multirow[t]{2}{*}{$\mathrm{CH}_{2 \mathrm{AS}}$} & - & $Y=0.01468-6.11098 \times 10^{-4} \mathrm{x}+5.39912 \times 10^{-6} \mathrm{x}^{2}$ \\
\hline & + & $Y=0.01728-6.20985 \times 10^{-4} \mathrm{x}+5.13111 \times 10^{-6} \mathrm{x}^{2}$ \\
\hline \multirow[t]{2}{*}{$\mathrm{CH}_{3 \mathrm{~S}}$} & - & $Y=0.00516-2.13888 \times 10^{-4} \mathrm{x}+2.39645 \times 10^{-6} \mathrm{x}^{2}$ \\
\hline & + & $\mathrm{Y}=0.00657-2.38644 \times 10^{-4} \mathrm{x}+2.27938 \times 10^{-6} \mathrm{x}^{2}$ \\
\hline \multirow[t]{2}{*}{$\mathrm{CH}_{2 \mathrm{~S}}$} & - & $Y=0.00876-3.63703 \times 10^{-4} \mathrm{x}+3.19257 \times 10^{-6} \mathrm{x}^{2}$ \\
\hline & + & $Y=0.01067-3.83149 \times 10^{-4} \mathrm{x}+3.17024 \times 10^{-6} \mathrm{x}^{2}$ \\
\hline
\end{tabular}


A

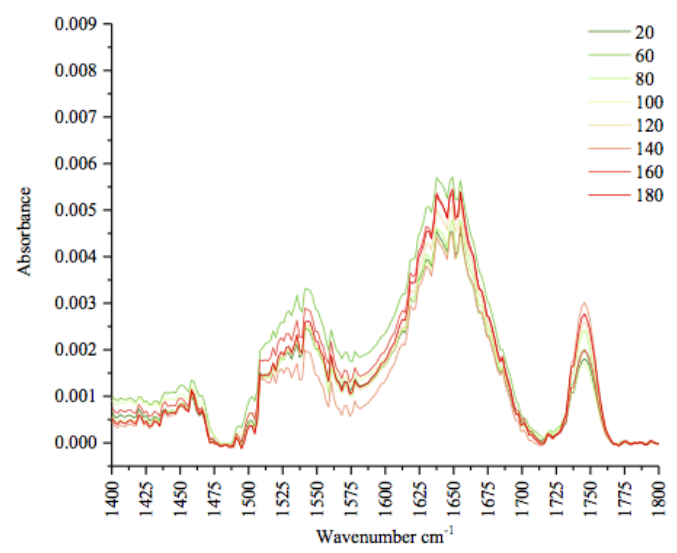

C

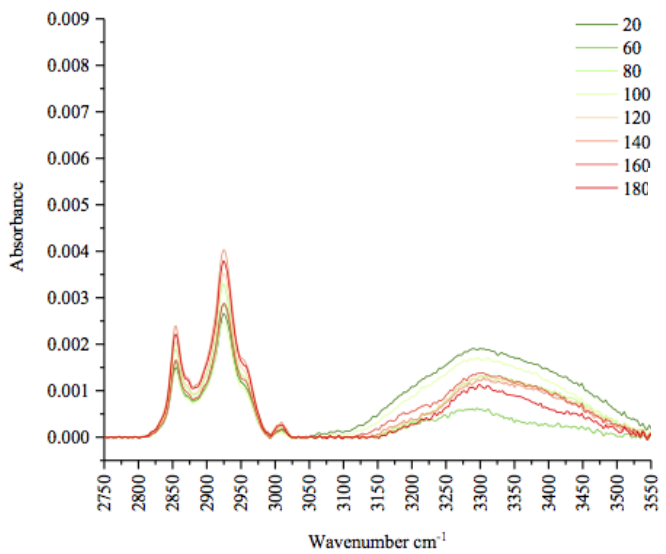

B

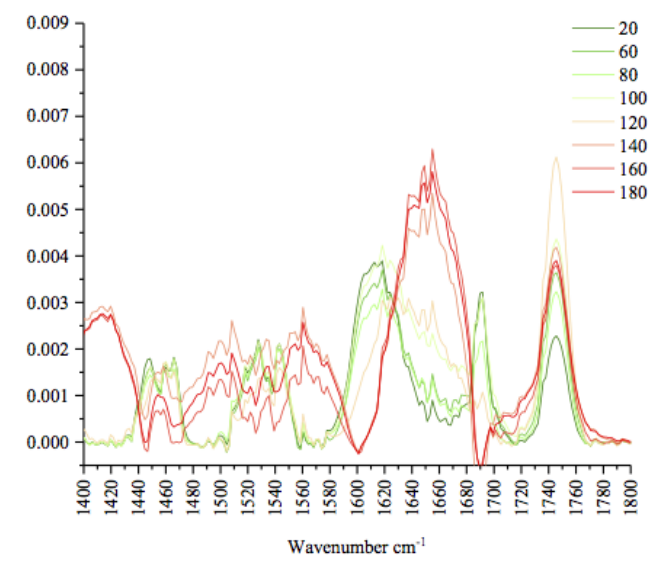

D

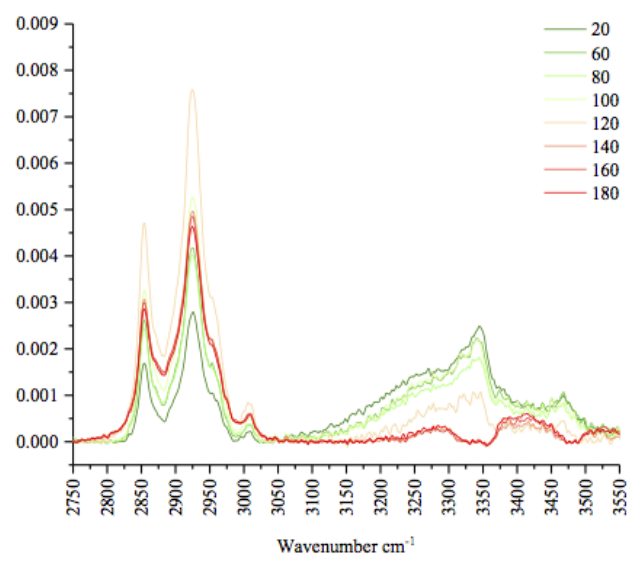

Figure A1. Attenuated total reflectance-Fourier transform infrared spectrum of canola meals produced at increasing barrel dry heat $\left(20\right.$ to $\left.180^{\circ} \mathrm{C}\right)$ with moist heat pressure (MHP) treatment $\left(120^{\circ} \mathrm{C} 15 \mathrm{~min} 192 \mathrm{kPa}\right)$. The total protein fingerprint region 1400 to $1800 \mathrm{~cm}^{-1}$ (A, B) and lipid related molecular region (C, D) of a single replicate are presented 
M $\quad 20 \quad 60 \quad 80100120140160180$ M
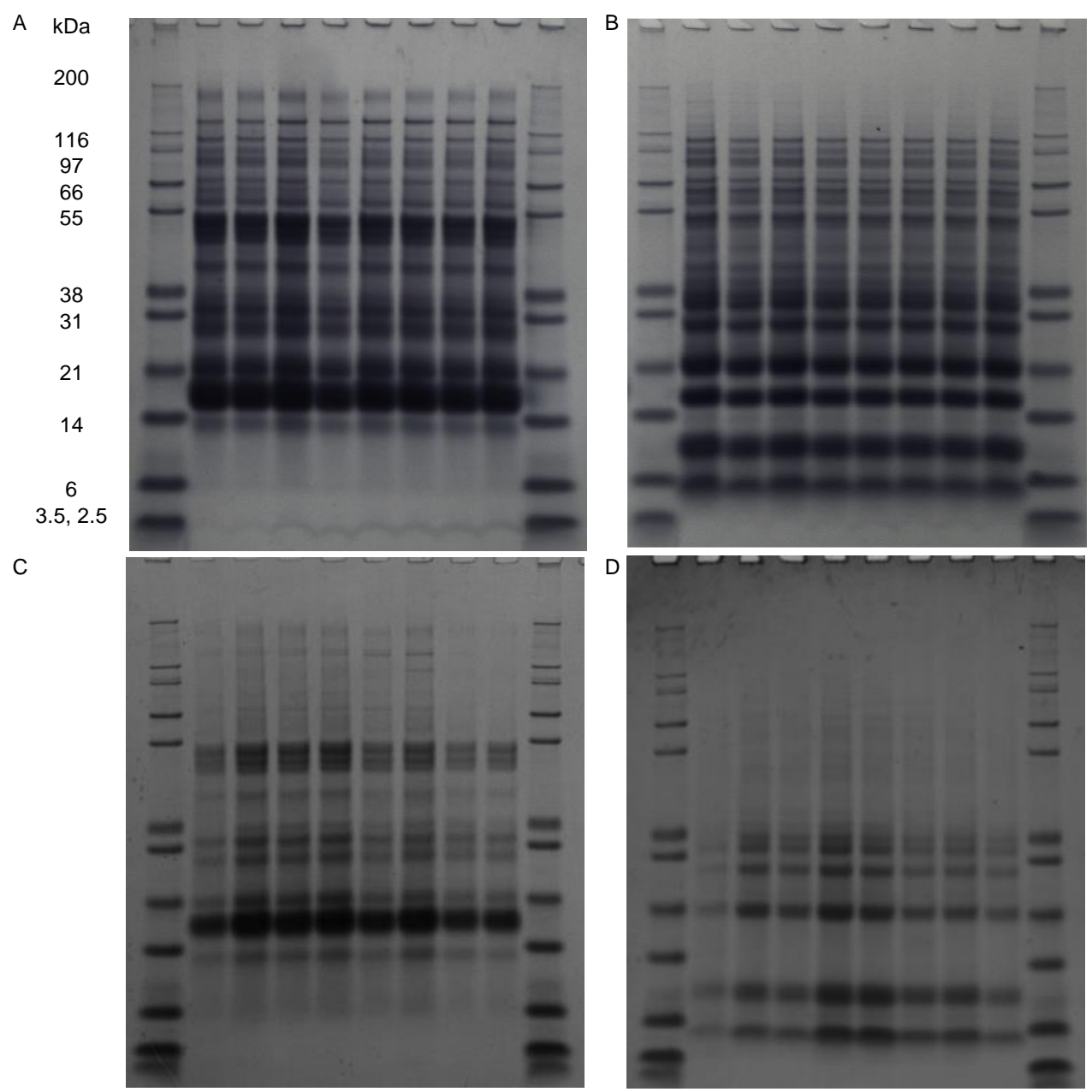

Figure A2. Representative SDS-PAGE protein profile of canola meal produced at increasing barrel dry heat (20 to $180^{\circ} \mathrm{C}$ ) revealed with coomassie blue stain. A $30 \mu \mathrm{g}$ aliquot of each sample was loaded per well.

Water soluble protein (A, B) and borate-phosphate buffer soluble protein (C, D). Non-reduced (A, C), reduced (B, D). A $5 \mu$ L aliquot of Mark 12 Unstained Protein Standard (M) was loaded 


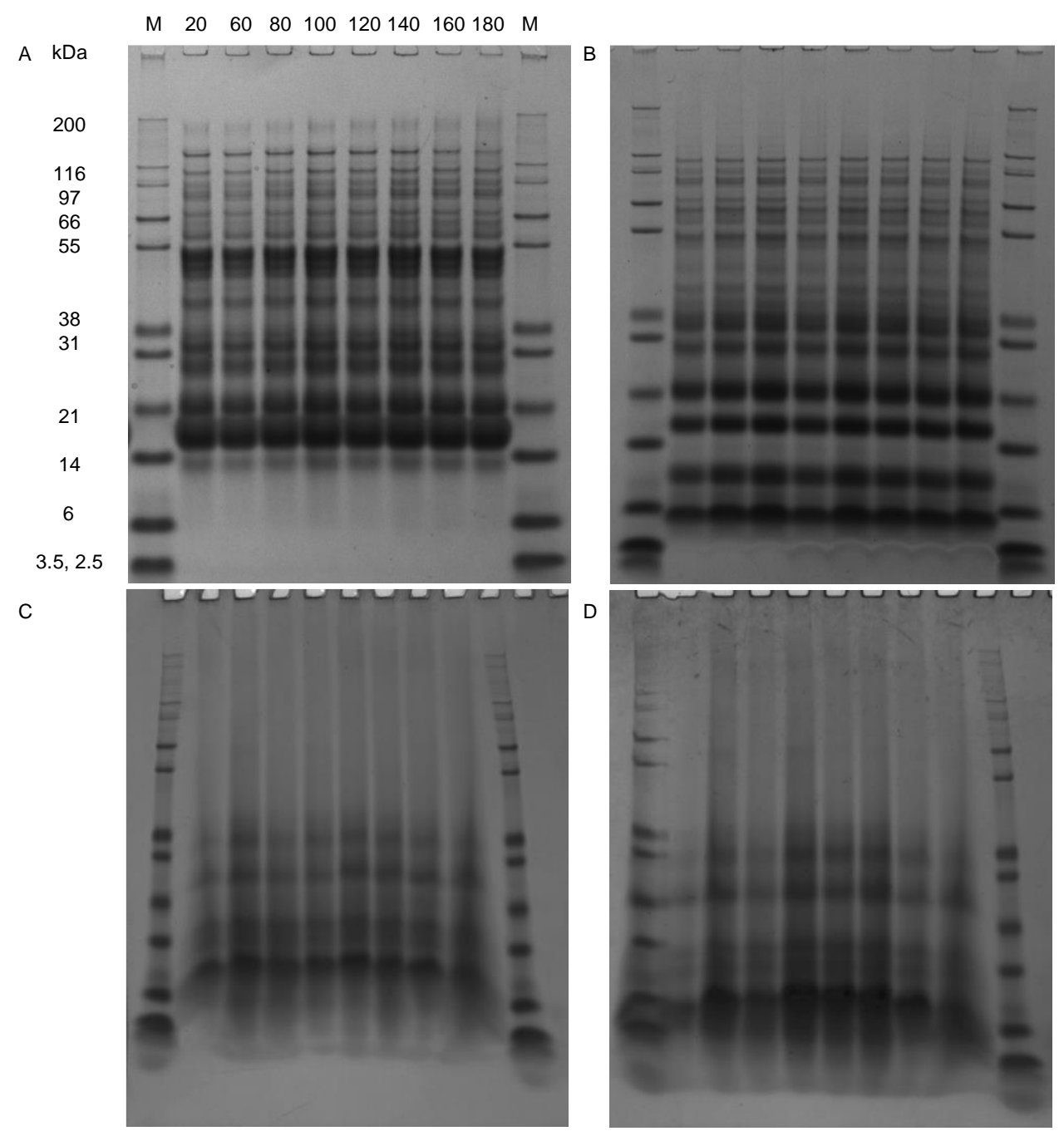

Figure A3. Representative SDS-PAGE protein profile of canola meal produced at increasing barrel dry heat (20 to $180^{\circ} \mathrm{C}$ ) with moist heat pressure (MHP) treatment $\left(120^{\circ} \mathrm{C}, 15 \mathrm{~min}, 192 \mathrm{kPa}\right)$ revealed with coomassie blue stain. A $30 \mu \mathrm{g}$ aliquot of each sample was loaded per well. Water soluble protein (A, B), and borate-phosphate buffer soluble protein (C, D). Non-reduced (A, C), reduced (B, D). A $5 \mu \mathrm{L}$ aliquot of Mark 12 Unstained Protein Standard (M) was loaded 
m $\quad 20 \quad 60 \quad 80100120140 \quad 160180 \quad$ m

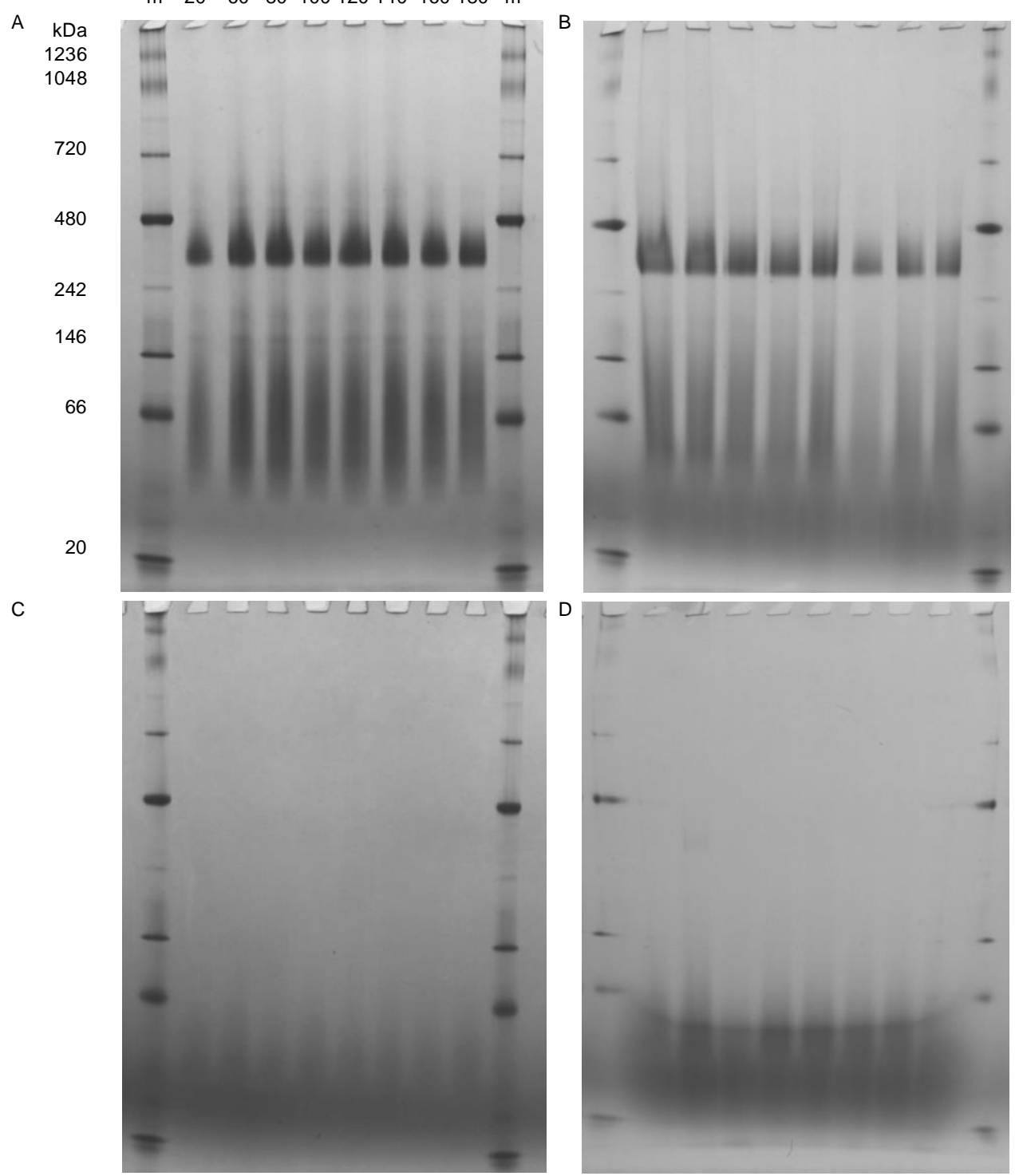

Figure A4. Representative native gel electrophoresis protein profile of canola meal produced at increasing dry heat $\left(20\right.$ to $\left.180^{\circ} \mathrm{C}\right)$ without (A, B) and with (C, D) moist heat pressure (MHP) treatment $\left(120^{\circ} \mathrm{C}, 15 \mathrm{~min}, 192\right.$ $\mathrm{kPa})$ revealed with coomassie blue stain. A $30 \mu \mathrm{g}$ aliquot of each sample was loaded per well. Water soluble protein (A, C), and borate-phosphate buffer soluble protein (B, D). A $5 \mu \mathrm{L}$ aliquot of NativeMark unstained protein standard $(\mathrm{m})$ was loaded 


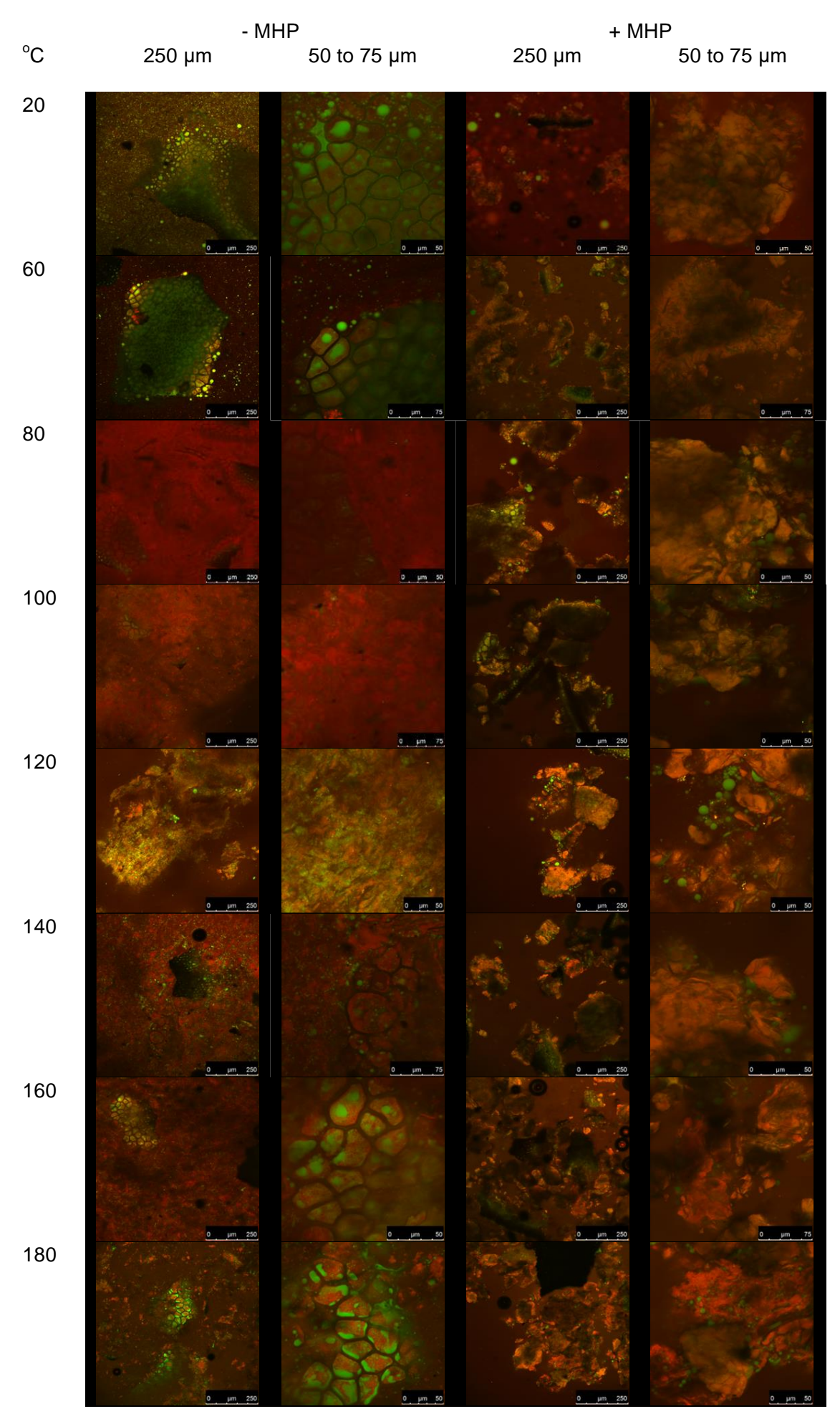

Figure A5. Representative confocal laser scanning micrographs of canola produced at increasing dry heat (20 to $\left.180^{\circ} \mathrm{C}\right)$ with moist heat pressure (MHP) treatment $\left(120^{\circ} \mathrm{C}, 15 \mathrm{~min}, 192 \mathrm{kPa}\right)$. Protein is stained red with Nile blue dye, and lipid is stained green with Fast green FCF dye. Scale bars correspond to 250, 75, or $50 \mu \mathrm{m}$ 


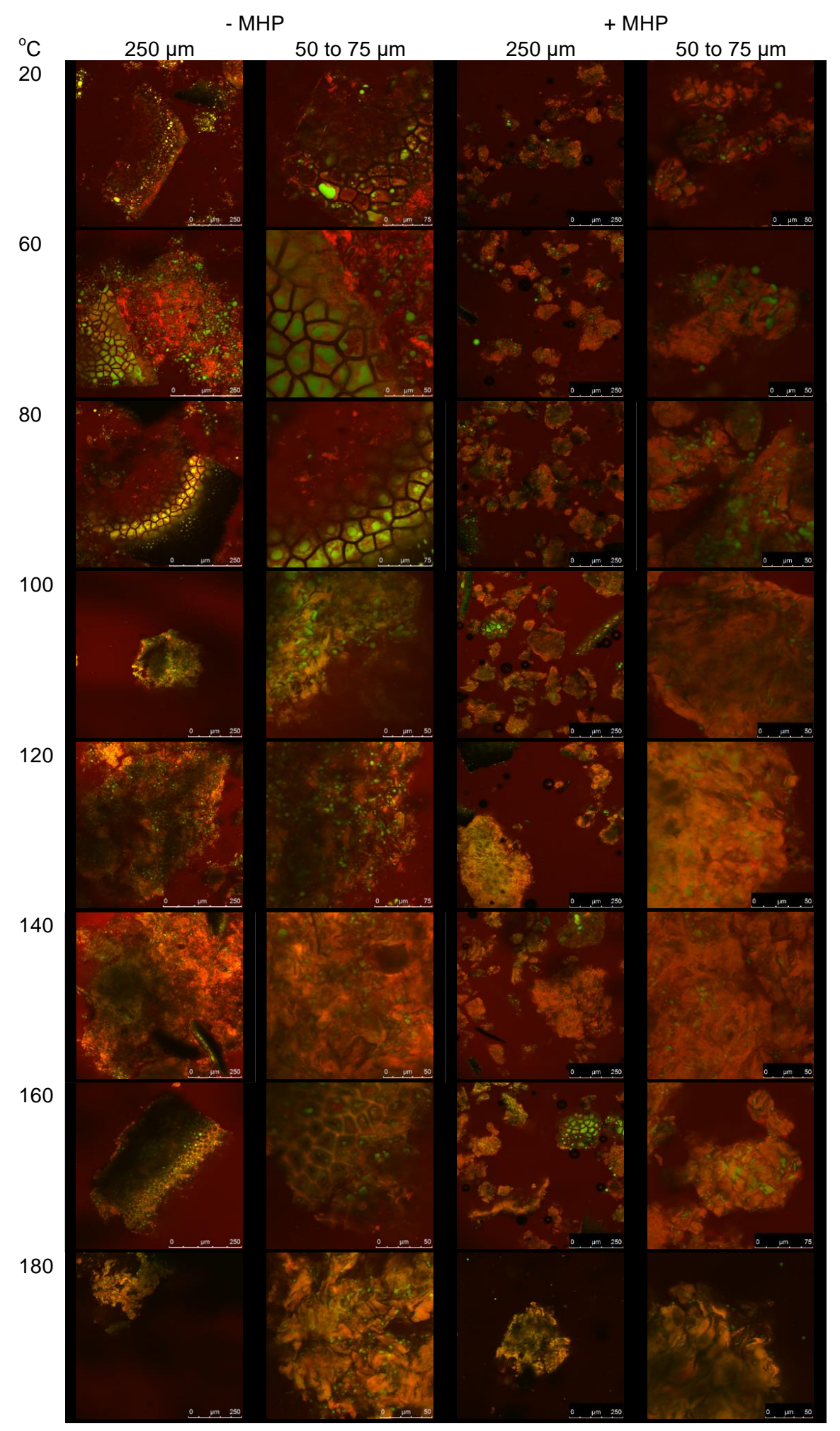

Figure A6. Representative confocal laser scanning micrographs of canola produced at increasing barrel dry heat $\left(20\right.$ to $180^{\circ} \mathrm{C}$ ) with moist heat pressure (MHP) treatment $\left(120^{\circ} \mathrm{C} 15 \mathrm{~min} 192 \mathrm{kPa}\right)$, post-proteolytic digestion.

Protein is stained red with Nile blue dye, and lipid is stained green with fast green FCF dye. Scale bars correspond to 250,75 , or $50 \mu \mathrm{m}$ 


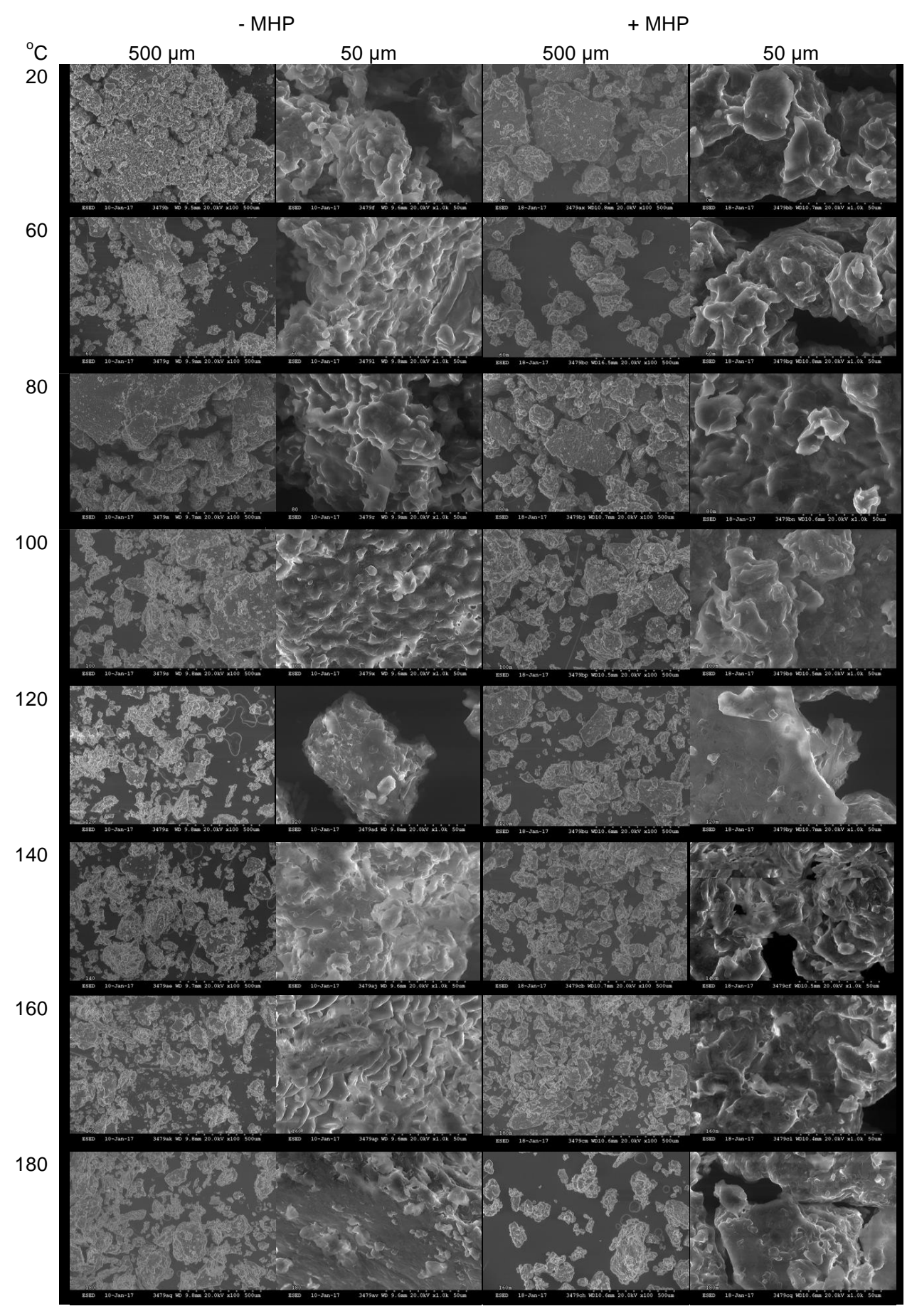

Figure A7. Representative scanning electron photomicrographs of canola meal produced at increasing barrel dry heat then treated with moist heat pressure (MHP) $\left(120^{\circ} \mathrm{C}, 15 \mathrm{~min}, 192 \mathrm{kPa}\right)$. Images were taken with $\times 1.0 \mathrm{k}$ and $\times 100$ resolution 


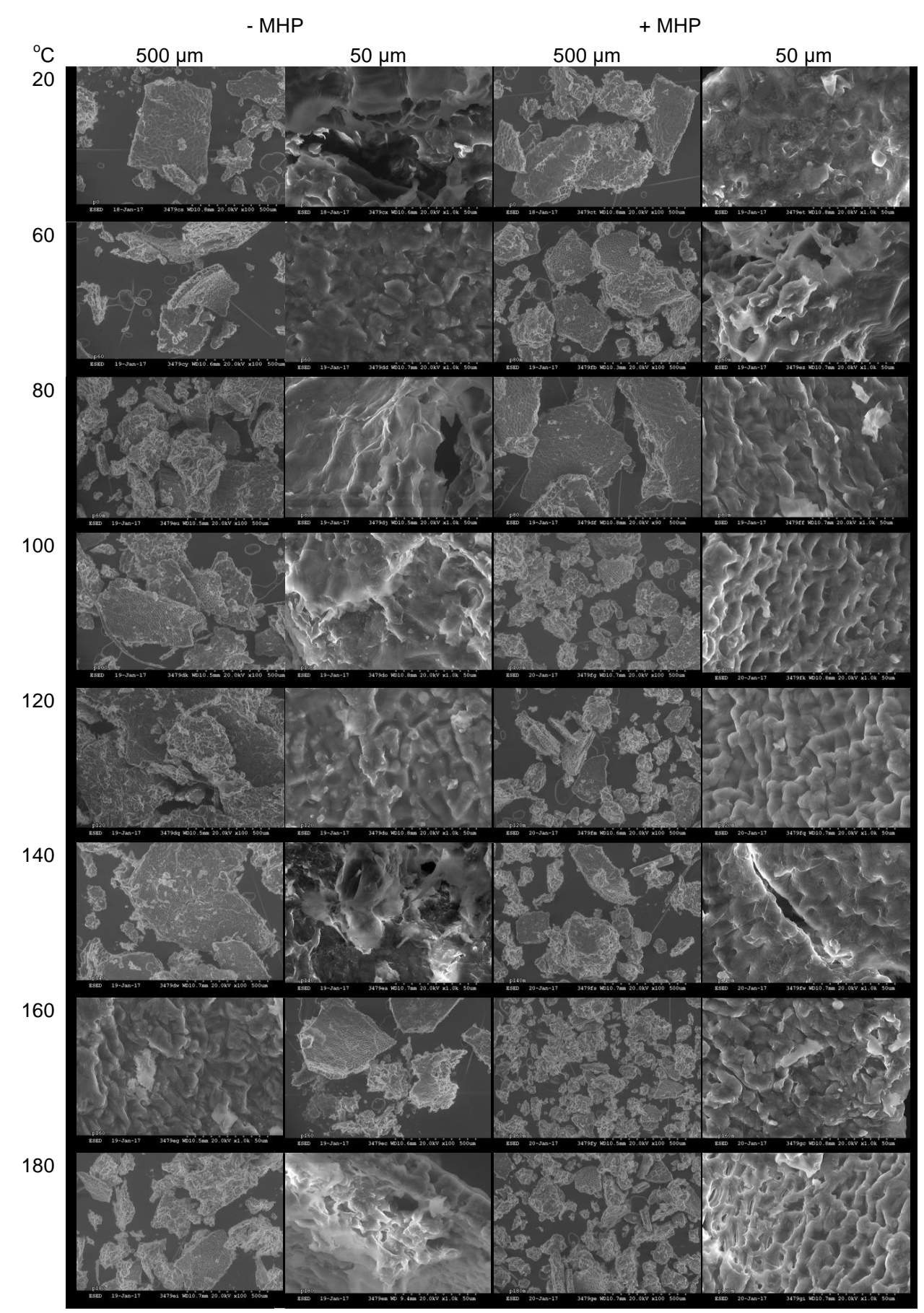

Figure A8. Representative scanning electron photomicrographs of canola meal produced at increasing dry heat then treated with moist heat pressure (MHP) $\left(120^{\circ} \mathrm{C}, 15 \mathrm{~min}, 192 \mathrm{kPa}\right)$ post proteolytic-digestion. Images were taken with $\times 1.0 \mathrm{k}$ and $\times 100$ resolution

\section{Copyrights}

Copyright for this article is retained by the author(s), with first publication rights granted to the journal.

This is an open-access article distributed under the terms and conditions of the Creative Commons Attribution license (http://creativecommons.org/licenses/by/4.0/). 